\title{
The Effect of Institutions on the External Financing of Brazilian Firms
}

\author{
Antonio Gledson de Carvalho*
}

\begin{abstract}
This article examines the effect of the level of institutional development across the different Brazilian states on the choice of external financing of Brazilian firms. Our analysis is based on a unique dataset, the Investment Climate Survey (ICS) of the Worldbank, stratified to be representative across size; 13 federal states; and 9 industry sectors. Our main results indicate that corruption and inefficiency of the judicial system have a negative impact on the access to bank credit and formal sources of funds. Financial development has a positive impact on the use of the same sources. Furthermore, this effect is more severe on smallest firms. These results suggest that low institutional development can foster financial repression, making firms rely more intensively on informal sources of funds or, otherwise, limit their investments. It also suggests that institutional underdevelopment has the perverse effect of promoting industrial concentration.
\end{abstract}

Keywords: external financing; institutional development; corruption; inneficiency of the judicial system; financial development.

JEL codes: G21; G33; N26; 016.

\section{Resumo}

Este artigo examina o efeito que a diferença no desenvolvimento institucional entre os diversos estados brasileiros exerce sobre as escolhas feitas pelas empresas brasileiras no que tange as suas fontes de financiamento externo. Nossa análise baseia-se em um banco de dados único - o Investment Climate Survey (ICS) do Banco Mundial - que foi extratificado para ser representativo entre os diferentes tamanhos de empresas, 13 estados da federação e nove setores industriais. Nossa análise indica que corrupção e ineficiência do sistema judiciário exercem efeito negativo no acesso ao crédito bancário e fontes formais de financiamento. $\mathrm{O}$ desenvolvimeto financeiro exerce efeito positivo sobre as mesmas fontes. Além do mais, tais efeitos são mais severos sobre pequenas empresas. Estes resultados sugerem que baixo desenvolvimento institucional reforça a repressão financeira, fazendo com que as empresas tenham que recorrer mais intensamente a fontes informais de recursos, ou de outro modo, limitar seus investimentos. Também sugerem que baixo desenvolvimento institucional tem o efeito perverso de promover a concentração industrial.

Submitted in August 2008. Accepted in November 2008. Article was double blind referred and evaluated by the editors. Supervising editor: Jairo Procianoy. This article was developed under financial support from the Worldbank, FAPESP (Project 03/08825-7) and CNPq (Process 477572/20030). Solange Kileber, Rodrigo Tolentino and Humberto Gabrielli are acknowledged for their excellent research assistance. The author is grateful to Ricardo Leal, Marco Da Rin and two anonymous referees. Any errors or omissions are of my exclusive responsibility.

*Fundação Getulio Vargas School of Business at Sao Paulo - FGV-EAESP. Rua Itapeva, 474, $7^{\circ}$ andar, São Paulo, SP, Brazil, 01332-000. Tel: (5511) 3281-7767, Fax (5511) 3262-3662.

Email: gledson.carvalho@fgv.br 
Palavras-chave: fontes de financiamento; desenvolvimento institucional; corrupção; ineficiência do sistema judiciário; desenvolvimento financeiro.

\section{Introduction}

Corporate financing choices are determined by a combination of factors that are related to the characteristics of the firm as well as to its environment. While a large literature focuses on the importance of firm's characteristics, only recently some effort has been dedicated to understand how the environment affects those choices. More recently some studies based on cross-country analysis have been focusing on how institutional environment affect finance (e.g., La Porta et al. (1997, 1998); Demirgüç-Kunt and Maksimovic (1996, 1998, 1999); Booth et al. (2001), Rajan and Zingales (1998), Beck et al. (2008); and Love (2003). However, several factors that are country specific may also affect financing choices, e.g., macroeconomic conditions (Campello (2003) and Levy (2007) and product market competition (Levy, 2007). This study focuses on how the level of institutional development across the different Brazilian states explains the choice of external ${ }^{1}$ financing of Brazilian firms. By using a cross-state approach we eliminate the country specific factors, improving the assessment of the effects of institutional environment.

There is no universal theory explaining corporate choices of financing or capital structure. ${ }^{2}$ The competing theories differ in their relative emphasis on the factors that could influence the choices between debt and equity. The main theories are: 1) capital-structure irrelevance (Modigliani and Miller, 1958) for which firm value and investment decisions are independent of financing and, consequently the choice between debt and equity is unimportant; 2) Trade-off theory: the financing choice results from the balance between the tax advantages of debt (Modigliani and Miller, 1963, Miller, 1977) and the costs of financial distress that arises with indebtedness. The costs of financial distress can be direct or indirect. Direct costs are those incurred during bankruptcy or reorganization. Indirect costs are mostly agency costs arising from the fact that common stock is equivalent to a call option on the firm's assets, with an exercise value equal to the face value of the debt (Black and Scholes, 1973). Due to this option nature of equity, managers can increase the value of the equity at the expenses of the debtholders by i) increasing risk by substituting assets (Jensen and Meckling, 1976); ii) contracting new debt and paying the extra money as dividends (this increases the risk of default, occasioning a value reduction of the old debt); iii) cutting back equity-financed capital investments; and iv) concealing problems to mask financial insolvency and postpone liquidation or reorganization (e.g., liquidating assets to generate cash). Other indirect costs of financial distress occur when customers, clients and employees

\footnotetext{
${ }^{1}$ External refers to all sources of financing not generated internally by the firm.

${ }^{2}$ The number of contributions in this area is so large that any literature review always bears the risk of omitting important contributions. In view of this, we will list the main theories and their key articles. There are also several ways in which one could organize this literature. In this short review, we follow the approach used in Myers (2003).
} 
bear cost in case the firm terminates; 3) pecking-order (Myers, 1984, Myers and Majluf, 1984): postulate that financing choices are consequence of asymmetrical information existing between corporate insiders and outside investors. The desire of managers to protect old stockholders interest may lead the firm to follow a pecking order according to which firms prefer to finance their investments firstly with internal funds, then with debt and, only in last case, with new equity issues; and 4) Agency theory (Jensen and Meckling, 1976): when the interest of managers and stockholders are not perfectly aligned, financing decisions have a important effect because they change managers' incentives and their investment and operating decisions. These four approaches are mostly suited to corporations that are public, non-financial firms raising capital from outside investors. When we extend our views to consider less well-established firms, we can list a fifth approach: 5) financial repression for which adverse selection and moral hazard can restrict firms in their capacity to obtain equity or debt financing (e.g., Stiglitz and Weiss (1981) and Shleifer and Wolfenzon (2002)).

Overall the theory suggests that imperfections resulting from conflict of interest and informational asymmetries between corporate insiders and investors constrain firms in their ability or desire to access the diverse sources of external financing. The magnitude of these imperfections depends on the level of institutional development. Firms that wish to obtain external funds must be able to commit to controlling opportunistic behavior by corporate insiders. For instance, outside capital suppliers use credit covenants and explicit fiduciary responsibilities to constrain opportunistic behavior by insiders. Institutional shortcomings may restrict corporate insiders' ability to commit to controlling opportunistic behavior. The efficiency of the judicial system and pervasive corruption are directly related to the complexity of contracts that firms can write and their enforcement. Weak judicial system and corruption may restrict financing arrangements to more conventional contracts such as debt vis-à-vis equity finance. This is so because debt provides a higher degree of monitoring ability and enforcement by investors (Smith and Warner, 1979) than an equity claim which provides little protection from expropriation by managers. Also, these institutional weaknesses make firms more likely to use short-term debt because it provides better protection to debt holders than longterm debt. In the limit, pervasive corruption and inefficiency of the judicial system may cause firms to be credit constrained and force them to rely on informal sources of funds. Nonetheless, politically connected firms in a corrupt environment may have better access to external financing.

Institutional development also can have a differentiated effect on small and large firms. For instance, small firms could suffer the most with the lack of financial development because large firms are able to internalize many of the capital allocation functions carried out by the financial system. From another hand, it is also possible that large firms suffer the most (Beck et al., 2005): large firms are most likely to tax the resources of an underdeveloped financial or legal system, since they are more likely than small firms to depend on the long-term financing 
and on larger loans. Therefore, it is possible that financial development can disproportionately reduce the effects of institutional obstacles on the largest firms. The access to external capital may depend on corporate insiders committing to control opportunistic behavior. When the judicial system does not work properly, the complexity of the contracts involved in such commitment and their enforcement my render this option unavailable to small firms.

Empirical evidence support the importance of the institutional environment on corporate choices of financing: using cross-country analysis, La Porta et al. (1997, 1998), Demirgüç-Kunt and Maksimovic (1996, 1998, 1999), Booth et al. (2001), Rajan and Zingales (1998), Beck et al. (2008) and Love (2003) present evidence that the country's legal and financial environment influences firm's use of external financing. Beck et al. (2008) point out that empirical results in these papers, while consistent with the corporate finance theory, are based on narrow evidence that does not support generalization. Their main shortcomings are that they 1) compare the largest firms of each country (maybe the least representative); 2) consider only two sources of external funds, debt and equity, not taking into consideration that firms may use other sources; and 3) although investigate access to external capital, they do not model the firm-level self-selection that occurs when accessing a particular source of financing.

Using a dataset composed of a large proportion of small and medium size firms, considering several sources of external financing, and controlling for the firm-level self selection, Beck et al. (2008) find that the proportion of the firms' investments that are funded through external financing does not depend on institutional development. However, in underdeveloped countries, firms are less able to obtain regular, formal debt and equity financing and, therefore, have to rely on other sources of funds (family and friends, governmental investment funds, credit cards, informal money lender, etc.). In turn, the specific form of external financing used is predicted by institutional development. They also find that large firms are more likely to use external financing in more developed financial systems and that firm size is one of the determinants of whether firms access a particular source.

Because of data availability, most studies on corporate choices of financing and capital structure in Brazil are based on publicly traded companies, e.g., Barros and Da Silveira (2007) and Procianoy and Schnorrenberger (2004). ${ }^{3}$ However, public companies are not representative of the Brazilian economy: they are mostly large firms, concentrated in some few industrial sectors and their number is too small when compared to the economy size. Research based on large firms can not provide answers about how certain factors distinctively affect small and large firms.

This article investigates the role of institutions and size on the pattern of external financing of Brazilian firms. We follow Beck et al. (2008) methodology by also considering sources of funds other than formal debt and equity finance and modeling the firm-level self-selection that occurs when accessing a particular source

\footnotetext{
${ }^{3}$ See Leal and Da Silva (2007) for a more complete review of this literature.
} 
of financing. We use a cross-state approach based on the existing variation across Brazilian states in terms of corruption, inefficiency of the judicial system and financial development. Our analysis is based on a unique dataset, the Investment Climate Survey (ICS) of the Worldbank. This dataset is representative across size (71.9\% of the sample are firms with less than 100 employees); 13 federal states; and 9 industry sectors. Such a rich dataset allow us to more precisely investigate the effect of size on financing patterns.

In the Brazilian context, this article relates to Pinheiro and Cabral (1998) and De Carvalho (2008). Pinheiro and Cabral found that the inefficiency of the judicial system affects the amount of aggregate credit for the Brazilian states. De Carvalho found that 1) shortcomings of institutional development, when measured in terms of corruption and inefficiency of the judicial system have a negative impact on firm growth, 2) Financial development at the states level has a positive effect on growth and 3) that smallest firms are those who suffer the most with corruption and inefficiency of the judicial system and largest firms are the one that profit the most from financial development.

Our main results indicate that corruption and inefficiency of the judicial system have a negative impact on the access to bank credit and formal sources of funds. Financial development has a positive impact on the use of the same sources. When these indexes are interacted with dummies for size, one observes that in terms of corruption and inefficiency of the judicial system, smallest firms suffers the most. These results help to explain those in De Carvalho (2008). The rest of this article is organized as follow: Section 2 presents the data and variables. Section 3 discusses the econometric procedures. Section 4 presents the empirical result. Section 5 concludes.

\section{The Data}

This paper is based on a unique data set created by the World Bank, the Investment Climate Survey (ICS). The ICS comprises information on 1642 Brazilian non-financial firms with size ranging from 10 to 10.500 employees. The ICS was based on a detailed questionnaire covering planning, labor relations, business environment, human resources, capacity for innovation, infrastructure and inspections, financing aspects, and accounting data. The data collection was made by an interviewer hired for this purpose. To prevent miss-reporting, the Worldbank pledged, to the participating firms, that their answers would be kept confidential. Any information that could identify respondents was removed from the dataset. ${ }^{4}$

The ICS sample was drawn to be representative across size, industrial sectors and macro-regions. For sampling purposes, firms were stratified by size according to the following rule: micro firms have 19 employees or less; small, between 20 and 99; medium, between 100 and 499; and large, 500 or more. The nine industrial sectors covered are food processing, textiles, garments, shoes \& leather,

\footnotetext{
${ }^{4}$ Before accessing the ICS we had to sign a letter pledging confidentiality of the data.
} 
chemicals, machinery, electronics, auto-parts, and furniture. Table 1 describes the sample across industries and size: micro firms comprise $18.2 \%$ of the sample; small, 53.7\%; medium, 23.2\%; and large, 4.9\%. One should note that micro and small firms comprise $73.9 \%$ of the sample. The sectors that are most represented are garments $(26.9 \%)$ and furniture $(19.2 \%)$, and the least represented are chemicals $(5.1 \%)$ and electronics $(4.8 \%)$. With respect to geographical distribution, the sample was stratified across 13 of the Brazilian states: Amazonas, Bahia, Ceará, Goiás, Maranhão, Minas Gerais, Mato Grosso, Paraíba, Paraná, Rio de Janeiro, Rio Grande do Sul, Santa Catarina, and São Paulo. One should note that all the five Brazilian macro-regions are represented. Table 2 presents the distribution of the sample across states. As expected there is a heavy concentration on the states of the southeast (Minas Gerais, 14.1\%; Rio de Janeiro, 7.4\%; and Sao Paulo, 21.9\%) and south regions (Paraná, 11.1\%; Rio Grande do Sul, 11.6\%; and Santa Catarina, $10.6 \%$ ). The fact that the sample was stratified to be representative across size and industrial sectors and federal states minimizes concerns with sample biases.

Table 1

Sample distribution across industries and size

\begin{tabular}{|c|c|c|c|c|c|}
\hline \multicolumn{6}{|c|}{$\begin{array}{l}\text { This table describes the sample of the Investment Climate Survey for } \\
\text { Brazil. Only industrial firms were included. Firms are classified by size } \\
\text { according to the number of employees (including outsourcing). Micro } \\
\text { firms have } 19 \text { employees or less; small, between } 20 \text { and } 99 \text {; medium, } \\
\text { between } 100 \text { and } 499 \text {, large, } 500 \text { or more. Numbers in bold face are } \\
\text { absolute, while the small ones represent percentages. }\end{array}$} \\
\hline \multirow[t]{2}{*}{ Industry } & \multicolumn{4}{|c|}{ Firm Size } & \multirow[t]{2}{*}{ Total } \\
\hline & Micro & Small & Medium & Large & \\
\hline \multirow[t]{2}{*}{ Food Processing } & 16 & 42 & 52 & 17 & 127 \\
\hline & 12.6 & 33.1 & 40.9 & 13.4 & $100 \%$ \\
\hline \multirow[t]{2}{*}{ Textiles } & 23 & 42 & 29 & 12 & 106 \\
\hline & 21.7 & 39.6 & 27.4 & 11.3 & $100 \%$ \\
\hline \multirow[t]{2}{*}{ Garments } & 85 & 276 & 73 & 8 & 442 \\
\hline & 19.2 & 62.4 & 16.5 & 1.8 & $100 \%$ \\
\hline \multirow[t]{2}{*}{ Shoes \& Leather } & 26 & 99 & 38 & 10 & 173 \\
\hline & 15.0 & 57.2 & 22.0 & 5.8 & $100 \%$ \\
\hline \multirow[t]{2}{*}{ Chemicals } & 10 & 52 & 16 & 6 & 84 \\
\hline & 11.9 & 61.9 & 19.0 & 7.1 & $100 \%$ \\
\hline \multirow[t]{2}{*}{ Machinery } & 40 & 84 & 51 & 8 & 183 \\
\hline & 21.9 & 45.9 & 27.9 & 4.4 & $100 \%$ \\
\hline \multirow[t]{2}{*}{ Electronics } & 7 & 56 & 12 & 4 & 79 \\
\hline & 8.9 & 70.9 & 15.2 & 5.1 & $100 \%$ \\
\hline \multirow[t]{2}{*}{ Auto-parts } & 15 & 60 & 44 & 11 & 130 \\
\hline & 11.5 & 46.2 & 33.8 & 8.5 & $100 \%$ \\
\hline \multirow[t]{2}{*}{ Furniture } & 76 & 170 & 65 & 4 & 315 \\
\hline & 24.1 & 54.0 & 20.6 & 1.3 & $100 \%$ \\
\hline \multirow[t]{2}{*}{ Total } & 298 & 883 & 381 & 80 & 1.642 \\
\hline & 18.2 & 53.7 & 23.2 & 4.9 & 100 \\
\hline
\end{tabular}

The ICS also has information that allowed us to construct variables characterizing firms. These variables are 1) age: numbers of years for which the firm has been operating; 2) employment: number of employees including outsourced ones; 3) sales: total sales for the year of 2000; 4) foreign: a dummy variable indicating firms for which more than $50 \%$ of the property belongs to foreigners; 5) 
immobilization: firms reported the value of total and fixed assets. For each year the immobilization rate was calculated as the rate of fixed to total assets. The variable immobilization corresponds to the average of the immobilization rate over the years 2000 to $2002 ; 6)$ growth: defined as the percent growth in sales between 2000 and 2002; 7) anonymous society: a dummy variable indicating firms that due to their legal status have to comply with specific rules - including accounting principles and disclosure. This category includes all publicly traded companies; 8) publicly traded: a dummy variable indicating companies listed in some stock exchange and subjected to CVM (Brazilian SEC) regulation; 9) operations abroad: a dummy variable indicating firms that reported some operation abroad; 10) $e x$ porter: a dummy variable indicating firms that export; and 11) economic group: a dummy variable indicating firms that belong to an economic group. Table 3 summarize these variables

Table 2

Sample distribution across brazilian federal states and size

\begin{tabular}{|c|c|c|c|c|c|}
\hline \multirow{2}{*}{ State } & \multicolumn{4}{|c|}{ Firm Size } & \multirow{2}{*}{ Total } \\
\hline & Micro & Small & Medium & Large & \\
\hline \multirow[t]{2}{*}{ Amazonas } & $\mathbf{0}$ & 16 & 6 & 2 & 24 \\
\hline & 0 & 66.7 & 25.0 & 8.3 & 100 \\
\hline \multirow[t]{2}{*}{ Bahia } & 18 & 48 & 9 & 1 & 76 \\
\hline & 23.7 & 63.2 & 11.8 & 1.3 & 100 \\
\hline \multirow[t]{2}{*}{ Ceará } & 15 & $\mathbf{5 0}$ & 18 & 7 & 90 \\
\hline & 16.7 & 55.6 & 20.0 & 7.8 & 100 \\
\hline \multirow[t]{2}{*}{ Goiás } & 23 & 45 & 12 & 3 & 83 \\
\hline & 27.7 & 54.2 & 14.5 & 3.6 & 100 \\
\hline \multirow[t]{2}{*}{ Maranhão } & 4 & 15 & 6 & $\mathbf{0}$ & 25 \\
\hline & 16.0 & 60.0 & 24.0 & 0.0 & 100 \\
\hline \multirow[t]{2}{*}{ Minas Gerais } & 43 & 120 & 58 & 11 & 232 \\
\hline & 18.5 & 51.7 & 25.0 & 4.7 & 100 \\
\hline \multirow[t]{2}{*}{ Mato Grosso } & 13 & 16 & 9 & $\mathbf{0}$ & 38 \\
\hline & 34.2 & 42.1 & 23.7 & 0.0 & 100 \\
\hline \multirow[t]{2}{*}{ Paraíba } & 11 & 26 & 9 & 1 & 47 \\
\hline & 23.4 & 55.3 & 19.1 & 2.1 & 100 \\
\hline \multirow[t]{2}{*}{ Paraná } & 29 & 100 & 48 & 5 & 182 \\
\hline & 15.9 & 54.9 & 26.4 & 2.7 & 100 \\
\hline \multirow[t]{2}{*}{ Rio de Janeiro } & 28 & 71 & 21 & 1 & 121 \\
\hline & 23.1 & 58.7 & 17.4 & 0.8 & 100 \\
\hline \multirow[t]{2}{*}{ Rio Grande do Sul } & 24 & 93 & 61 & 12 & 190 \\
\hline & 12.6 & 48.9 & 32.1 & 6.3 & 100 \\
\hline \multirow[t]{2}{*}{ Santa Catarina } & 36 & 78 & 46 & 14 & 174 \\
\hline & 20.7 & 44.8 & 26.4 & 8.0 & 100 \\
\hline \multirow[t]{2}{*}{ São Paulo } & 54 & 205 & 78 & 23 & 360 \\
\hline & 15.0 & 56.9 & 21.7 & 6.4 & 100 \\
\hline \multirow[t]{2}{*}{ Total } & 298 & 883 & 381 & 80 & 1.642 \\
\hline & 18.1 & 53.8 & 23.2 & 4.9 & 100 \\
\hline
\end{tabular}


Table 3

Variables description

\begin{tabular}{|c|c|c|}
\hline \multirow{5}{*}{$\begin{array}{l}\text { Sources of } \\
\text { financing }\end{array}$} & Bank credit & $\begin{array}{l}\text { All formal sources of loans, e.g., commercial banks and of- } \\
\text { ficial sources }\end{array}$ \\
\hline & Formal sources & $\begin{array}{l}\text { Funds from a formal credit institution, including leasing and } \\
\text { credit cards }\end{array}$ \\
\hline & Owners & All funds proceeding from stockholders, including debt \\
\hline & Informal sources & $\begin{array}{l}\text { Fund not proceeding from formal sources, i.e., funds from } \\
\text { owners, family and friends, informal money lender, etc. }\end{array}$ \\
\hline & Trade credit & $\begin{array}{l}\text { Funds generated from the operations of the firm, i.e., leasing } \\
\text { and credit from clients and suppliers; }\end{array}$ \\
\hline \multirow{4}{*}{ Corruption } & Inspection & $\begin{array}{l}\text { This index was obtained from the ICS. It represents the pro- } \\
\text { portion, by federal state, of firms that reported some infor- } \\
\text { mal cost related to an inspection from the labor or welfare } \\
\text { departments. }\end{array}$ \\
\hline & Government contracts & $\begin{array}{l}\text { It is based on the percentage, in relation to the value of the } \\
\text { contract that the entrepreneur believes necessary to pay in } \\
\text { the form of gratification to have a contract with the govern- } \\
\text { ment respected. This index corresponds to the average across } \\
\text { states. }\end{array}$ \\
\hline & Tax issues & $\begin{array}{l}\text { For each state it corresponds to the ratio of firms that reported } \\
\text { some informal cost related to a visit from a fiscal authority } \\
\text { of any level (Federal, State, or City) and the number of the } \\
\text { firms that were visited by at least one of these authorities. }\end{array}$ \\
\hline & General index & $\begin{array}{l}\text { Corresponds to the average of the three primitive indexes } \\
\text { (each of the three primitive corruption indexes was scaled } \\
\text { in a way that its maximum value observed was ten). }\end{array}$ \\
\hline \multirow[b]{2}{*}{ Inefficiency } & Cost & $\begin{array}{l}\text { These indexes were extracted from Pinheiro and Cabral } \\
\text { (1998). They were constructed from two surveys in which }\end{array}$ \\
\hline & Velocity & $\begin{array}{l}\text { entrepreneurs classified the judicial system as very good, } \\
\text { good, regular, bad, or very bad with respect to three }\end{array}$ \\
\hline \multirow[t]{2}{*}{ of the judicial } & Criteria: justice & $\begin{array}{l}\text { justice, speed, and costs. For each criterion, the index corre- } \\
\text { sponds to the proportion of respondents that }\end{array}$ \\
\hline & General index & $\begin{array}{l}\text { classified the judicial system as bad or vary bad. The general } \\
\text { index corresponds to the average of these three indexes. }\end{array}$ \\
\hline \multirow[b]{3}{*}{ Development } & Branches to GDP & $\begin{array}{l}\text { Number of bank branches in the state divided by the State } \\
\text { GDP. }\end{array}$ \\
\hline & Branches to population & $\begin{array}{l}\text { Number of bank branches in the state divided by its popula- } \\
\text { tion. }\end{array}$ \\
\hline & Branches forecast error & $\begin{array}{l}\text { The prediction error of the number of bank branches rela- } \\
\text { tive to the predicted number of branches, where the predic- } \\
\text { tion was obtained in a regression of the number of branches } \\
\text { against GDP, land area, and population. }\end{array}$ \\
\hline Age & \multicolumn{2}{|c|}{ Number of years for which the firm has been operating. } \\
\hline Sales & \multicolumn{2}{|c|}{ Total sales for the year of 2000} \\
\hline Growth & \multicolumn{2}{|c|}{ The percent growth in sales between 2000 and 2002} \\
\hline Firm size & \multicolumn{2}{|c|}{$\begin{array}{l}\text { Classification based on sales in } 2000 \text { according to the following rule: micro firms had } \\
\text { sales below } \operatorname{Br} \$ 400,000 \text {; small, between } \operatorname{BR} \$ 400,000 \text { and } \operatorname{Br} \$ 1,200,000 \text {; medium be- } \\
\text { tween } \operatorname{BR} \$ 1,200,000 \text { and } \operatorname{Br} \$ 7,623,031 \text {; and large, above } \operatorname{Br} \$ 7,623,031 \text {. }\end{array}$} \\
\hline Immobilization & \multicolumn{2}{|c|}{ Average of fixed to total assets over the years 2000 to 2002} \\
\hline Exporter & \multicolumn{2}{|c|}{ Dummy variable indicating firms that are exporters. } \\
\hline Foreign & \multicolumn{2}{|c|}{$\begin{array}{l}\text { Dummy variable indicating firms for which more than } 50 \% \text { of the property belongs to } \\
\text { foreigners. }\end{array}$} \\
\hline Operations abroad & \multicolumn{2}{|c|}{ Dummy variable indicating firms that reported some operation abroad. } \\
\hline Economic group & \multicolumn{2}{|c|}{ Dummy variable indicating firms that belong to an economic group. } \\
\hline Profitability & \multicolumn{2}{|c|}{ Ratio of sales minus raw materials, energy, labor and managerial expenses to sales. } \\
\hline Industrial sector & \multicolumn{2}{|c|}{$\begin{array}{l}\text { Dummy variables for } 9 \text { industrial sectors: food, textiles, garments, shoes and leather, } \\
\text { chemicals, machinery, electronics, automobiles and auto-parts, and furniture. }\end{array}$} \\
\hline
\end{tabular}


Using the ICS and other publicly available data we could compute some indexes that capture the institutional development at the state level for each of the 13 Brazilian states in our sample (Table 3 present a summary of these indexes). From the ICS, using data for 2002, we obtained three primitive indexes measuring corruption: 1) inspections (corruption related to inspections of the Labor and Social Security Office): for each state, this index is calculated as the ratio between the number of firms that reported some informal cost related to an inspection from the Labor or Social Security Office and the number of firms that were inspected; 2) government Contracts (corruption in contracts with the government): based on the percentage, in relation to the value of the contract, that the entrepreneur believes it is necessary to pay in the form of gratification to have a contract with the government respected. This index is computed as the average opinion in the state; 3) tax issues (corruption in tax issues): for each state it correspond to the ratio of firms that reported some informal cost related to a visit from a fiscal authority of any level (Federal, State, or City) and the number of the firms that were visited by at least one of these authorities; and 4) general corruption index: corresponds to the average ${ }^{5}$ of the three primitive indexes. The three primitive indexes capture different aspects of corruption and, consequently, carry a certain error. One would expect their average to be a finer index.

The indexes for the inefficiency of the judicial system were borrowed from Pinheiro and Cabral (1998). These indexes were constructed from two surveys in which entrepreneurs classified the judicial system of their states as very good, good, regular, bad, and very bad with respect to three criteria: justice, velocity, and cost. For each criterion, the index corresponds to the proportion of respondents that classified the judicial system as bad or very bad. The general index was computed as the average of these three primitive indexes. Once again, we expect that the average of the primitive indexes represents a finer index.

As indexes of financial development we use scaled measures of the number of branches of banks in the state for the year of 1996, namely 1) bank branches-topopulation, 2) bank branches-to-GDP and 3) branches predicted error: calculated as the difference between the actual number of bank branches and the predicted number of branches, divided by the predicted number of branches (the prediction was obtained in a regression of the number of branches against GDP, land area, and population). The raw data used to compute the financial development indexes were obtained from the Brazilian Central Bank, Institute for Applied Economic Research (IPEA) and Brazilian Institute for Geography and Statistics (IBGE).

${ }^{5}$ To take the average, each of the three corruption primitive indexes was scaled in a way that its maximum value observed was ten. 
Table 4 reports the institutional development indexes described in the last paragraphs. Even though the rankings generated by each of the primitive indexes are different, some patterns can be observed. The states with worst performance in terms of corruption are Ceara, Rio de Janeiro (between the five states with worst performance in all rankings generated by the primitive indexes), and São Paulo and Paraná (between the five states with worst performance in two rankings). The states with best performance in terms of corruption are Mato Grosso (between the five states with best performance in all rankings), and Santa Catarina, Rio Grande do Sul, Minas Gerais and Bahia (between the five states with best performance in two rankings). The states with best performance in terms of judicial system are Rio Grande do Sul (always between the five states with best performance), and Minas Gerais, Santa Catarina and Amazonas (between the five states with best performance in two rankings). Some of the states with worst judicial performance are Mato Grosso (always between the five states with worst performance), and Ceara, Paraná and Goiás (between the five states with worst performance in two rankings). Table 5 reports the correlation across indexes. One can observe that even though these indexes in blocks seek to measure the same aspects of institutional development, their correlation is considerably low inside groups (near 0.5) and generally very low across groups. 
Table 4

\begin{tabular}{|c|c|c|c|c|c|c|c|c|c|c|c|c|}
\hline \multirow[b]{2}{*}{ State } & \multicolumn{4}{|c|}{ Corruption } & \multicolumn{4}{|c|}{ Inefficiency of Judicial System } & \multicolumn{3}{|c|}{$\begin{array}{l}\text { Financial Developnent } \\
\end{array}$} & \multirow[b]{2}{*}{$\begin{array}{c}\text { GDP } \\
\text { per } \\
\text { capita }\end{array}$} \\
\hline & Inspections & $\begin{array}{l}\text { Contracts } \\
\text { with } \\
\text { government }\end{array}$ & $\begin{array}{c}\text { Tax } \\
\text { issues }\end{array}$ & $\begin{array}{l}\text { General } \\
\text { index }\end{array}$ & Cost & Velocity & Justice & General & $\begin{array}{c}\text { Branches/ } \\
\text { POP }\end{array}$ & $\begin{array}{c}\text { Branches/ } \\
\text { GDP }\end{array}$ & $\begin{array}{c}\text { Branches } \\
\text { forecast } \\
\text { error }\end{array}$ & \\
\hline Amazonas & 0.0 & 12.5 & 17.7 & 4.50 & 0.60 & 0.60 & 0.2 & 0.47 & 5.2 & 1.1 & -0.22 & 4.84 \\
\hline Bahia & 0.29 & 10.6 & 1.9 & 3.44 & 0.49 & 0.82 & 0.46 & 0.59 & 6.2 & 2.1 & -0.17 & 2.98 \\
\hline Ceará & 0.58 & 16.8 & 20.3 & 7.90 & 0.38 & 1.00 & 0.38 & 0.59 & 5.3 & 2.3 & -0.26 & 2.31 \\
\hline Goiás & 0.23 & 15.4 & 4.9 & 4.51 & 0.60 & 0.87 & 0.27 & 0.58 & 12.3 & 2.9 & 0.42 & 4.08 \\
\hline Maranhão & 0.0 & 12.5 & 5.0 & 3.05 & 0.50 & 1.00 & 0.25 & 0.58 & 5.0 & 2.6 & -0.21 & 1.67 \\
\hline Minas Gerais & 0.25 & 9.9 & 3.0 & 3.28 & 0.39 & 0.87 & 0.23 & 0.50 & 10.9 & 2.0 & 0.12 & 5.36 \\
\hline Mato Grosso & 0.0 & 9.0 & 3.4 & 2.17 & 0.67 & 1.00 & 0.33 & 0.67 & 10.9 & 2.4 & 0.42 & 4.40 \\
\hline Paraíba & 0.0 & 12.2 & 4.6 & 2.95 & 0.75 & 0.75 & 0.25 & 0.58 & 5.1 & 2.3 & -0.30 & 2.10 \\
\hline Paraná & 0.42 & 11.4 & 12.5 & 5.32 & 0.51 & 0.93 & 0.27 & 0.57 & 13.9 & 2.3 & 0.33 & 5.93 \\
\hline Rio de Janeiro & 0.25 & 13.5 & 29.2 & 6.98 & 0.52 & 0.91 & 0.22 & 0.55 & 10.0 & 1.3 & -.016 & 7.47 \\
\hline Rio Grande do Sul & 0.11 & 8.7 & 1.2 & 2.29 & 0.41 & 0.82 & 0.17 & 0.47 & 14.4 & 2.2 & 0.30 & 6.61 \\
\hline Santa Catarina & 0.0 & 14.3 & 2.7 & 3.15 & 0.40 & 0.89 & 0.21 & 0.50 & 16.3 & 2.8 & 0.54 & 5.76 \\
\hline São Paulo & 0.86 & 11.7 & 12.1 & 7.04 & 0.33 & 0.91 & 0.24 & 0.49 & 14.1 & 1.4 & -0.01 & 10.08 \\
\hline
\end{tabular}


Our endogenous variables are the proportions that the sources of external capital represented in the financing for new investments in the year of 2002. The ICS classified the sources of capital into 11 categories: 1) internal funds or retained earnings; 2) local commercial banks; 3) foreign commercial banks; 4) leasing; 5) official sources, i.g., official investment funds, development banks; 6) credit from suppliers or clients; 7) credit cards; 8) increase in capital, sales of new stocks, and credit from stockholders; 9) family and friends; 10) informal sources, e.g., informal money lender; and 11) other sources. We grouped the external sources (items 2 to 11 above) into five categories: 1) bank credit: encompassing all the sources of formal loans, i.e., loans from local and foreign commercial banks and official sources; 2) owners: representing the funds coming from stockholders either as equity or debt; 3 ) trade credit: all the funds generated from the operations of the firm, i.e., leasing and credit from clients and suppliers; 4) formal sources: funds from a formal credit institution, i.e., credit from local and foreign commercial banks, official sources, leasing and credit cards; and 5) informal sources: all the sources not included among the formal sources, i.e., equity, family and friends, and other informal sources. One should note that these five sources of external financing are not mutually exclusive.

\section{Econometric Analysis}

Our variables of interest are the proportion of every form of external capital in the funding of new investments. The decision to obtain external financing and the choice of each particular form of financing are endogenous. Unless this is taken into consideration, estimates of the correlation between the proportion of a particular source of financing and firms' characteristics may be biased. For such situations, Heckman's two-step procedure is recommended: in the first step we obtain the probability of each firm using a particular source of financing. From this estimation, we obtain the non-selection hazard for each observation (inverse of the Mill's ratio). In the second stage, we estimate the proportions with the set of regressors being augmented with the inclusion of the non-selection hazard. The equation for the first step has the form

$$
\begin{aligned}
\text { financing dummy } & =\alpha+\beta \text { firm individual characteristics } \\
& +\gamma \text { institutional variables } \\
& +\delta \text { financial obstacle revealed }+\mu
\end{aligned}
$$

while the equation for the second step has the form

$$
\begin{aligned}
\text { financing proportion } & =\alpha+\beta \text { firm individual characteristics } \\
& +\gamma \text { Institutional variable } \\
& +\delta \text { non-selection hazard }+\epsilon
\end{aligned}
$$




\begin{tabular}{|c|c|c|c|c|c|c|c|c|c|c|c|c|}
\hline & & \multicolumn{4}{|c|}{ Corruption } & \multicolumn{4}{|c|}{ Inefficiency of judicial system } & \multicolumn{3}{|c|}{$\begin{array}{l}\text { Financial development } \\
\end{array}$} \\
\hline & & \begin{tabular}{|c|} 
Inspections \\
contracts
\end{tabular} & $\begin{array}{c}\text { Government } \\
\text { issues }\end{array}$ & \begin{tabular}{|c|} 
Tax \\
index \\
\end{tabular} & General & Cost & Velocity & Justice & $\begin{array}{c}\text { General } \\
\text { index } \\
\end{array}$ & \begin{tabular}{|c|} 
Branches $/$ \\
POP
\end{tabular} & \begin{tabular}{|c|} 
Branches $/$ \\
GDP
\end{tabular} & \begin{tabular}{|c} 
Branches \\
forecast error
\end{tabular} \\
\hline \multirow{3}{*}{ Corruption } & Government Contracts & 0.21 & & & & & & & & & & \\
\hline & \begin{tabular}{|c|} 
Tax Issues \\
\end{tabular} & 0.36 & $0.48^{*}$ & & & & & & & & & \\
\hline & General index & $0.77^{* * * *}$ & $0.61^{* *}$ & $0.83^{* * * *}$ & & & & & & & & \\
\hline \multirow{4}{*}{$\begin{array}{l}\text { Inefficiency of } \\
\text { judicial system }\end{array}$} & Cost & -0.60 ** & -0.08 & \begin{tabular}{|c|}
-0.08 \\
\end{tabular} & -0.38 & & & & & & & \\
\hline & Velocity & 0.31 & 0.13 & 0.01 & 0.21 & -0.32 & & & & & & \\
\hline & Justice & 0.26 & 0.11 & -0.07 & 0.13 & 0.06 & 0.30 & & & & & \\
\hline & General Index & -0.11 & 0.07 & -0.07 & -0.79 & $0.52 *$ & $0.54^{*}$ & $0.68^{* *}$ & & & & \\
\hline \multirow{4}{*}{$\begin{array}{l}\text { Financial } \\
\text { development }\end{array}$} & Branches / POP & 0.20 & -0.19 & -0.21 & -0.05 & -0.40 & 0.22 & \begin{tabular}{|c|}
-0.41 \\
\end{tabular} & -0.32 & & & \\
\hline & branches / GDP & -0.28 & 0.18 & $-0.61^{* *}$ & -0.43 & 0.12 & 0.46 & 0.21 & 0.47 & 0.19 & & \\
\hline & \begin{tabular}{|l|} 
branches forecast error \\
\end{tabular} & -0.14 & -0.20 & -0.45 & -0.36 & -0.10 & 0.25 & -0.23 & -0.01 & $0.85^{* * * *}$ & 0.51 & \\
\hline & GDP per capita & $0,48^{*}$ & $-0,24$ & 0,26 & 0,33 & $-0,47$ & $-0,02$ & 0.42 & $-0,55^{*}$ & $0,75^{* * * *}$ & $-0,50^{*}$ & 0,33 \\
\hline
\end{tabular}

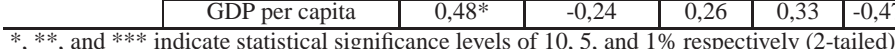


The institutional variables are 1) the several measures of corruption, inefficiency of the judicial system and financial development, and 2) the several measures of institutional development interacted with the size dummies for micro, small, medium, and large firms.

Our approach follows Beck et al. (2008), where the explanatory variables of the second stage are the same as those of the first stage, with the exception of the variables financial obstacle revealed. The variables financial obstacle revealed were obtained from qualitative questions in which firms were asked to rate the importance of 1) access to credit (e.g., collateral) and 2) costs of financing (e.g., interest rates) to the growth and operations of the firm. The answers ranged from "it is not an obstacle" (rate 0) to "it is a very severe obstacle" (rate 4).

While the institutional indexes reflect specific aspects of institutional development, each one of them can be related to other aspects of the institutional development of the Brazilian state. As consequence, we can find spurious corelation. To mitigate this problem, when the interest variable is an institutional development index, we include the GDP per capita of the state where the firm has its headquarters as control variable.

The individual characteristics of the firm used as control must be those that matter for financing choices. As pointed out in Section 1, finance theory suggests that the factors that constrain firms in their ability or desire to access the diverse sources of external financing are tax shields, costs of financial distress, and imperfections resulting from conflict of interest and informational asymmetries between corporate insiders and investors. Usually these characteristics are associated to high business risk, with unusual growth opportunities, intangible assets, uniqueness of the business, high asymmetrical information, etc. The empirical variables commonly used as proxy for these characteristics in studies focusing on public companies are size, age, profitability, growth, R\&D expenses, volatility of earnings, industrial sector, etc. Our corresponding empirical variables are age, sales, growth in sales, immobilization and industrial sector dummy variables. We do not have data on i) R\&D expenses, because this information is not mandatory in Brazilian financial reports and ii) volatility of earnings since our dataset contains a large set of small, privately held companies. On the other hand, we control for several characteristics that are important in a small-firm context. This control is made through the inclusion of dummy variables for firms 1) that belong to an economic group and have foreign control: such firms may have the backing of associated firms (e.g., guarantees in loans). Moreover, capital can be raised in one firm and transferred to another one in the form of equity infusion or loan from equity holders or other informal source of fund; 2) export and mantain operations abroad: such firms have access to specific lines of credit, present some sophistication in their line of products, are less subjects to informality in their business, etc.; 3) are publicly traded: these firms have to comply with specific laws and face the oversight from the Comissão de Valores Imobiliários (Brazilian SEC) and other capital markets agents; and 4) are incorporated as an anonymous society: these firms have 
accounting standards and disclosure rules established in law and that are stronger than those established for other firms.

\section{Empirical Results}

Tables 6 to $9 \mathrm{~b}$ present the empirical analysis of the determinants of external sources of financing for new investments of Brazilian firms. Table 6 reports the effects of firm's individual characteristics only. Restricting our attention only to statistically significant results, one can be see that: 1) size and growth are the only factors that explain the use of bank credit. Large firms have more access and use a larger proportion of bank credit. The higher the growth, the less is the proportion of bank credit; 2) the use of formal sources is conditioned by size, growth, foreign proprietorship and exportation. The access to formal sources increases with size and is smaller for foreign firms. The proportion of formal sources increases with size and is smaller for firms that grow fast and export; 3) financing from owners is influenced by age, immobilization, foreign control, incorporation as anonymous society, exportation activity and belonging to an economic group. Old firms and those incorporated as anonymous society less frequently use funds coming from stockholders, while firms with foreign control, that export and belong to an economic group more frequently use those funds. The proportion of financing from owners seems to be affected only by the degree of immobilization; 4) the use of informal source is less frequent for firm that are old, large and incorporated as anonymous society, and more frequent for those that have foreign control, belong to an economic group, and present high degree of immobilization. The proportion of informal sources decreases with immobilization and is larger for firms with foreign control; and 5) the use of trade credit is more frequent for old firms and those with operations abroad, while the proportion of this source of funds decreases with size and growth. 
Table 6

Determinants of external finance

Heckman two-step estimation for the model Proportion of financing source $=\alpha+\beta$ firm individual characteristics $+\epsilon$. In the first step, we also included as exogenous variables the level of financial obstacle reported by the firm with respect access to credit and cost of credit. Age is the number of years the firms has been operating. Ln (sales) is the natural logarithm of sales in 2000. Profitability is defined as sales minus raw materials, energy, labor and managerial expenses divided by sales in 2002. Growth is the percent growth in sales between 2000 and 2002. Immobilization is the average of the ratio of fixed to total assess for the years 2000-2002. Publicly traded, Anonymous Society, Economic group, exporter, Foreign and Operations abroad are dummy variables indicating, respectively, publicly trade firms, firms that due to its incorporation form are bound to disclosure rules whether the firm is part of an economic group, exports, is controlled by foreigners and maintains operations abroad. Bank credit includes all the sources of formal loans. Formal sources are funds from a formal credit institution. Owners represent the funds coming from stockholders as equity or loans. Informal sources are all the sources not included among the formal sources. Trade credit represents all the funds generated from the operations of the firm. All regressions include dummy variables for industry sectors. The t-statistics are in parentheses.

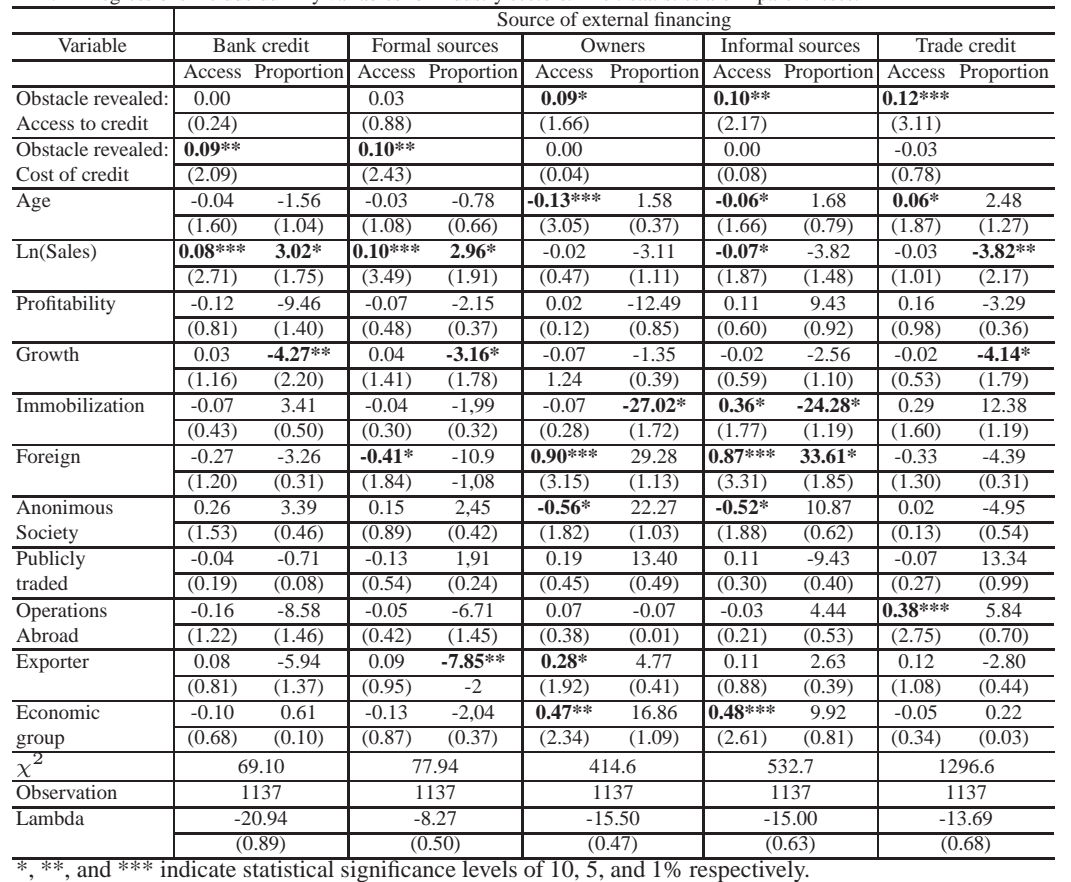

Tables 7 and 8 assess the effect of corruption at the state level on external financing. The several indexes of corruption present 1) a negative and statistically significant effect on the access to bank credit (three out of four indexes are statistically significant), formal sources (all four indexes are statistically significance) and trade credit (two out of four indexes are statistically significant) and 2) a positive and statistically significant effect on the proportion of informal sources and trade credit. 
When the corruption indexes are interacted with the size of the firms we observe that 1) the negative effect of corruption on the access to bank credit, formal sources and trade credit is more frequently felt by micro, small and medium firms. Moreover the magnitude of the effect tends to be greater for micro and small firms. Corruption never presents statistically significant impact on large firms; and 2) the positive effect of corruption on the proportion of trade credit is felt by all size of firms. There is not a clear pattern on how corruption differently affects the proportion of informal sources for small and large firms.

Overall, corruption seems to have a negative effect on the access to bank credit, formal sources and trade credit, and this effect seems to be more severe on smallest firms. Corruption also seems to cause firms to use a higher proportion of trade credit and informal sources, even though one can not distinguish whether this effect is affected by the size of the firm.

Table 7

Effects of Institutional Development on External Finance - Corruption

Heckman two-step estimation for the model Proportion of financing source $=\alpha+\beta$ firm individual characteristics $+\epsilon$. In the first step, we also included as exogenous variables the level of financial obstacle reported by the firm with respect access to credit and cost of credit. Age is the number of years the firms has been operating. $L n$ (sales) is the natural logarithm of sales in 2000. Profitability is defined as sales minus raw materials, energy, labor and managerial expenses divided by sales in 2002. Growth is the percent growth in sales between 2000 and 2002. Immobilization is the average of the ratios of fixed to total assess for the years 2000-2002. Publicly traded, Anonymous Society, Economic group, exporter, Foreign and Operations abroad are dummy variables indicating, respectively, publicly trade firms, firms that due to its incorporation form are bound to disclosure rules whether the firm is part of an economic group, exports, is controlled by foreigners and maintains operations abroad. Bank credit includes all the sources of formal loans. Formal sources are funds from a form

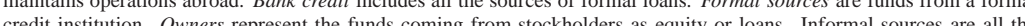
firm. All regressions include dummy variables for industry sectors. The t-statistics are in parentheses. firm. All regressions include dummy variables for industry sectors. The t-statistics are in parentheses.

\begin{tabular}{|c|c|c|c|c|c|c|c|c|c|c|}
\hline & \multicolumn{10}{|c|}{ Source of external financing } \\
\hline \multirow[t]{2}{*}{ Variable } & \multicolumn{2}{|c|}{ Bank credit } & \multicolumn{2}{|c|}{ Formal sources } & \multicolumn{2}{|c|}{ Owners } & \multicolumn{2}{|c|}{ Informal sources } & \multicolumn{2}{|c|}{ Trade credit } \\
\hline & Access & Proportion & Access & Proportion & Access & Proportion & Access & Proportion & Access & Proportion \\
\hline \multirow[t]{2}{*}{ Inspections } & $-0.52^{* * * *}$ & -3.02 & $-0.51^{* * * *}$ & -3.08 & -0.16 & 7.08 & -0.25 & 11.3 & -0.31 & $37.2 * * *$ \\
\hline & $(2.93)$ & $(0.27)$ & \begin{tabular}{|l|}
$(2.89)$ \\
\end{tabular} & $(0.35)$ & $(0.59)$ & $(0.35)$ & $(1.08)$ & $(0.78)$ & $(1.61)$ & $(3.50)$ \\
\hline$\chi^{2}$ & \multicolumn{2}{|c|}{80.9} & \multicolumn{2}{|c|}{86.8} & \multicolumn{2}{|c|}{396.1} & \multicolumn{2}{|c|}{\begin{tabular}{|l|}
515.4 \\
\end{tabular}} & \multicolumn{2}{|c|}{1403.0} \\
\hline Observation & \multirow{2}{*}{\multicolumn{2}{|c|}{$\begin{array}{c}1137 \\
-167\end{array}$}} & \multirow{2}{*}{\multicolumn{2}{|c|}{$\frac{1137}{-68}$}} & \multirow{2}{*}{\multicolumn{2}{|c|}{1137}} & \multicolumn{2}{|c|}{1137} & \multicolumn{2}{|c|}{1137} \\
\hline \multirow[t]{2}{*}{ Lambda } & & & & & & & \multirow{2}{*}{\multicolumn{2}{|c|}{$\frac{-19.8}{(0.78)}$}} & & 15.9 \\
\hline & \multicolumn{2}{|c|}{$(0.68)$} & \multicolumn{2}{|c|}{$(0.40)$} & \multicolumn{2}{|c|}{$(0.49)$} & & & \multicolumn{2}{|c|}{$(0.83)$} \\
\hline \multirow{2}{*}{$\begin{array}{c}\begin{array}{c}\text { Government } \\
\text { Contracts }\end{array} \\
\end{array}$} & -2.97 & 58.1 & $-3.80 \%$ & 2.10 & 0.98 & -73.2 & 2.30 & 74.7 & $-6.00 * * *$ & 85.4 \\
\hline & $(1.62)$ & $(0.71)$ & $(2.07)$ & $(0.03)$ & $(0.35)$ & $(0.41)$ & $(0.97)$ & $(0.53)$ & $(2.91)$ & $(0.67)$ \\
\hline$\chi^{2}$ & \multicolumn{2}{|c|}{75.5} & \multicolumn{2}{|c|}{83.0} & \multicolumn{2}{|c|}{409.3} & \multicolumn{2}{|c|}{\begin{tabular}{|l}
588.1 \\
\end{tabular}} & \multicolumn{2}{|c|}{1039.7} \\
\hline Observation & & 137 & & 137 & & 137 & & 137 & & 137 \\
\hline Lambda & & $\overline{18.2}$ & & 7.6 & & 5.2 & & 6.4 & & 14.6 \\
\hline & & $8.80)$ & & .47) & & 45) & & .65) & & .79) \\
\hline Tax issues & $-1.27 * *$ & $45.5^{*}$ & $-1.33^{* * * * *}$ & 30.6 & 0.74 & 2.85 & 0.36 & $64.7 *$ & -0.84 & $66.6^{* * *}$ \\
\hline & $(2.49)$ & (1.68) & $(2.65)$ & $(1.32)$ & $(0.99)$ & $(0.06)$ & $(0.57)$ & (1.94) & $(1.51)$ & $(2.30)$ \\
\hline$\chi^{2}$ & & 87.1 & & 1.3 & & 3.9 & & 17.5 & & 378.9 \\
\hline Observation & & 137 & & 137 & & 137 & & 137 & & 137 \\
\hline Lambda & & 14.5 & & 5.2 & & 6.5 & & 21.4 & & 11.5 \\
\hline & & D.66) & & .33) & & 48) & & $86)$ & & $.62)$ \\
\hline General & $-7.70^{* * *}$ & 99.5 & $-8.12 * * *$ & 47.0 & 1.18 & 73.6 & 0.00 & $388.4 * *$ & $-6.38 * *$ & $443.0^{* * * * *}$ \\
\hline & $(3.25)$ & $(0.67)$ & (3.43) & $(0.39)$ & $(0.32)$ & $(0.23)$ & $(0.00)$ & $(2.04)$ & $(2.39)$ & $(2.93)$ \\
\hline$\chi^{2}$ & & 86.7 & & 2.7 & & 93 & & 16 & & 328 \\
\hline observation & & 137 & & 137 & & 137 & & 137 & & 137 \\
\hline Lambda & & 15.2 & & 5.7 & & 6.0 & & 21.3 & & 0.60 \\
\hline & & $0.67)$ & & .35) & & 47) & & $86)$ & & $.14)$ \\
\hline
\end{tabular}




\section{Table 8}

Effects of institutional development on external financing - corruption and size

Heckman two-step estimation for the model Proportion of financing source $=\alpha+\beta+\lambda$ (interaction between state index and firm size) $+\epsilon$. In the first step, we also included as exogenous variables the level of financial obstacle reported by the firm with respect access to credit and cost of credit. The controls are: the number of years the firms has been operating; the natural logarithm of sales in 2000; profitability defined as sales minus raw materials, energy, labor and managerial expenses divided by sales in 2002; the growth in sales between 2000 and 2002; the immobilization defined the average of the ratios of fixed to total assess for the years 2000-2002; dummy variables indicating, respectively, publicly trade firms, firms that due to its incorporation form are bound to disclosure rules whether the firm is part of an economic group, exports, is controlled by foreigners and maintains operations abroad. Micro firms have 19 employees or less; small, between 20 and 99; medium, between 100 and 499; and large, 500 or more. Bank credit includes all the sources of formal loans. Formal sources are funds from a formal credit institution. Owners represent the funds coming from stockholders as equity or loans. Informal sources are all the sources not included among the formal sources. Trade credit represents all the funds generated from the operations of the firm. All regressions include dummy variables for industry sectors and the GDP per capita of the state where the firm is located. We report only the coefficient associated to the interaction between the institutional variable and firm size. These coefficients were multiplied by 100 . The z-statistics are in parentheses.

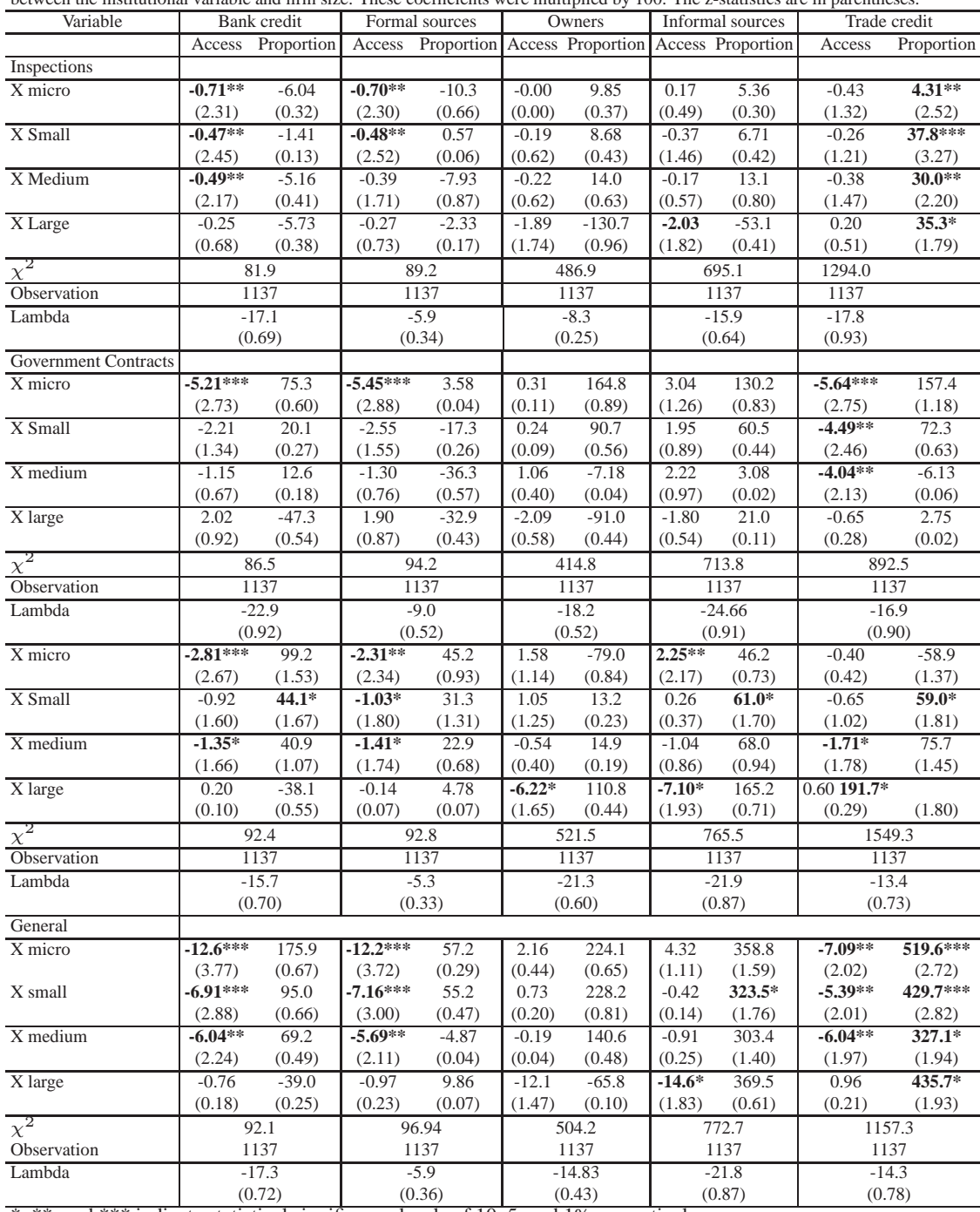

*,**, and $* * *$ indicate statistical significance levels of 10,5 , and $1 \%$ respectively. 
Tables 9 and 10 present the effect of the inefficiency of the judicial system on the external financing of Brazilian firms. The effect is similar to that of corruption on the access to bank credit, formal sources and trade credit: all the coefficients are negative. However the results are not statistically significant for all indexes. Only the general and justice indexes present statistical significance. Judicial inefficiency also seems to make firms rely more intensively on funds from owners and informal sources: the general and cost indexes present statistical significance on the access to such sources. Finally the only external source of financing of which the proportion is affected by judicial inefficiency is trade credit: the indexes velocity and justice present positive sign that is statistically significant (the general index is also marginally significant).

When the indexes of the inefficiency of the judicial system are interacted with size (Table 10), one can see that smallest firms suffer the most in terms of access to bank credit and formal sources. The sign of the interactions with micro and small dummies are always negative, even though only the criteria of justice and cost present statistical significance. Apparently medium and large firms do not suffer this negative impact (in some cases the coefficient is even positive and statistically significant for these firms). Judicial inefficiency makes small firms relay more intensively on funds coming from owners and informal sources than large firms.

Overall, the effect of the inefficiency of the judicial system is very similar to that of corruption: negative effect on the access to bank credit, formal sources and trade credit. This effect seems to be more severe on smallest firms. It also seems to cause firms to rely more on funds from owners and informal sources. This last effect is stronger on smallest firms. 
Table 9

Effects of institutional development on external finance - Inefficiency of judicial system

Heckman two-step estimation for the model Proportion of financing source $=\alpha+\beta+\lambda$ (interaction between state index and firm size) $+\epsilon$. In the first step, we also included as exogenous variables the level of financial obstacle reported by the firm with respect access to credit and cost of credit. The controls are: the number of years the firms has been operating; the natural logarithm of sales in 2000; profitability defined as sales minus raw materials, energy, labor and managerial expenses divided by sales in 2002; the growth in sales between 2000 and 2002; the immobilization defined the average of the ratios of fixed to total assess for the years 2000-2002; dummy variables indicating, respectively, publicly trade firms, firms that due to its incorporation form are bound to disclosure rules whether the firm is part of an economic group, exports, is controlled by foreigners and maintains operations abroad. Micro firms have 19 employees or less; small, between 20 and 99; medium, between 100 and 499; and large, 500 or more. Bunk credit include a credit represents all the funds generated from the operations of the firm. All regressions include dummy variables for industry sectors and the GDP per capita of the state where the firm is located. We report only the coefficient associated to the interaction between the institutional variable and firm size. These coefficients were multiplied by 100 . The z-statistics are in parentheses.

\begin{tabular}{|c|c|c|c|c|c|c|c|c|c|c|}
\hline Variable & \multicolumn{2}{|c|}{ Bank credit } & \multicolumn{2}{|c|}{ Formal sources } & \multicolumn{2}{|c|}{ Owners } & \multicolumn{2}{|c|}{ Informal sources } & \multicolumn{2}{|c|}{ Trade credit } \\
\hline & Access & Proportion & Access & Proportion & Access & Proportion & Access & Proportion & Access & Proportion \\
\hline Costs & $\begin{array}{l}-0.41 \\
(0.83)\end{array}$ & $\begin{array}{l}16.04 \\
(0.73)\end{array}$ & \begin{tabular}{|c|}
-0.44 \\
$(0.90)$
\end{tabular} & $\begin{array}{l}-4.39 \\
(0.22)\end{array}$ & $\begin{array}{l}\mathbf{1 . 5 7 * *} \\
(2.14)\end{array}$ & $\begin{array}{l}30.82 \\
(0.48)\end{array}$ & $\begin{array}{r}1.62^{* * * * 4} \\
(2.65)\end{array}$ & $\begin{array}{l}36.90 \\
(0.79)\end{array}$ & \begin{tabular}{|l|}
-0.51 \\
$(0.91)$
\end{tabular} & $\begin{array}{l}-1.47 \\
(0.05)\end{array}$ \\
\hline$\chi^{2}$ & \multicolumn{2}{|c|}{71.8} & \multicolumn{2}{|c|}{78.7} & \multicolumn{2}{|c|}{581.8} & \multicolumn{2}{|c|}{798.7} & \multicolumn{2}{|c|}{1212.9} \\
\hline Observation & \multicolumn{2}{|c|}{1137} & \multicolumn{2}{|c|}{1137} & \multicolumn{2}{|c|}{1137} & \multicolumn{2}{|c|}{1137} & \multicolumn{2}{|c|}{1137} \\
\hline Lambda & \multicolumn{2}{|c|}{$\begin{array}{l}-20.6 \\
(0.89)\end{array}$} & \multicolumn{2}{|c|}{$\begin{array}{c}-9.0 \\
(0.55)\end{array}$} & \multicolumn{2}{|c|}{$\begin{array}{l}-11.9 \\
(0.34)\end{array}$} & \multicolumn{2}{|c|}{$\begin{array}{l}-19.8 \\
(0.75)\end{array}$} & \multicolumn{2}{|c|}{$\begin{array}{l}-15.8 \\
(0.83)\end{array}$} \\
\hline Velocity & $\begin{array}{l}-0.26 \\
(0.40)\end{array}$ & $\begin{array}{c}-10.65 \\
(0.39)\end{array}$ & $\begin{array}{l}-0.69 \\
(1.07)\end{array}$ & $\begin{array}{c}6.79 \\
(0.26)\end{array}$ & $\begin{array}{c}1.56 \\
(1.55)\end{array}$ & $\begin{array}{l}63.88 \\
(0.89)\end{array}$ & $\begin{array}{c}0.19 \\
(0.24)\end{array}$ & $\begin{array}{l}30.32 \\
(0.74)\end{array}$ & $\begin{array}{l}-1.14 \\
(1.56)\end{array}$ & $\begin{array}{r}\mathbf{6 8 . 2 2} * \\
(1.70)\end{array}$ \\
\hline$\chi^{2}$ & \multicolumn{2}{|c|}{70.7} & \multicolumn{2}{|c|}{79.2} & \multicolumn{2}{|c|}{666.5} & \multicolumn{2}{|c|}{556.9} & \multicolumn{2}{|c|}{909.3} \\
\hline Observation & \multicolumn{2}{|c|}{1137} & \multicolumn{2}{|c|}{1137} & \multicolumn{2}{|c|}{1137} & \multicolumn{2}{|c|}{1137} & \multicolumn{2}{|c|}{1137} \\
\hline$\overline{\text { Lambda }}$ & \multicolumn{2}{|c|}{$\begin{array}{l}-20.4 \\
(0.87)\end{array}$} & \multicolumn{2}{|c|}{$\begin{array}{c}-8.5 \\
(0.52)\end{array}$} & \multicolumn{2}{|c|}{$\begin{array}{l}-34.4 \\
(0.96)\end{array}$} & \multicolumn{2}{|c|}{$\begin{array}{l}-19.6 \\
(0.79)\end{array}$} & & $\begin{array}{l}-13.6 \\
0.71)\end{array}$ \\
\hline Justice & $-1.44 * *$ & -39.56 & $-1.53 * \%$ & -33.80 & 0.92 & -18.55 & 0.71 & -25.1 & -0.81 & $69.89 \%$ \\
\hline & $(2.11)$ & $(1.08)$ & $(2.24)$ & $(1.10)$ & $(0.93)$ & $(0.29)$ & $(0.84)$ & $(0.56)$ & (1.06) & $(1.86)$ \\
\hline$\chi^{2}$ & & 78.1 & & 4.5 & & 52.2 & & 86.3 & & 225.2 \\
\hline Observation & & 137 & & 137 & & 137 & & 137 & & 1137 \\
\hline Lambda & & $\begin{array}{l}17.5 \\
0.73)\end{array}$ & & $\begin{array}{l}7.1 \\
.42) \\
\end{array}$ & & $\begin{array}{l}2.9 \\
129)\end{array}$ & & $\begin{array}{l}7.2 \\
71)\end{array}$ & & $\begin{array}{l}-14.9 \\
0.77)\end{array}$ \\
\hline General & $-1.72^{*}$ & -11.99 & $-219^{* * *}$ & -18.99 & $4.04^{* * * *}$ & 77.58 & $2.99 * *$ & 50.0 & $-2.04^{*}$ & 94.81 \\
\hline & $(1.69)$ & $(0.25)$ & $(2.16)$ & $(0.44)$ & $(2.65)$ & $(0.56)$ & $(2.31)$ & $(0.56)$ & $(1.78)$ & $(1.61)$ \\
\hline$\chi^{2}$ & & 73.4 & & 2.5 & & 72.9 & & 12.2 & & 802.3 \\
\hline$\overline{\text { Observation }}$ & & 137 & & 137 & & 137 & & 137 & & 1137 \\
\hline Lambda & & $\begin{array}{l}21.1 \\
0.90)\end{array}$ & & $\begin{array}{l}9.9 \\
60)\end{array}$ & & $\begin{array}{l}15.0 \\
.45)\end{array}$ & & $\begin{array}{l}21.4 \\
.85)\end{array}$ & & $\begin{array}{l}-12.4 \\
0.66)\end{array}$ \\
\hline
\end{tabular}


Table 10

Effects of institutional development on external finance - Inefficiency of judicial system and size

Heckman two-step estimation for the model Proportion of financing source $=\alpha+\beta$ firm individual characteristics $+\gamma$ Institutional factors $+\epsilon$. In the first step, we also included as exogenous variables the level of financial obstacle reported by the firm with respect access to credit and cost of credit. Age is the number of years the firms has been operating. Ln(sales) is the natural logarithm of sales in 2002. Profitability is defined as sales minus raw materials, energy, labor and managerial expenses divided by sales in 2000. Growth is the percent growth in sales between 2000 and 2002. Immobilization is the average of the ratios of fixed to total assess for the years 2000-2002. Publicly traded, Anonymous Society, Economic group, exporter, Foreign and Operations abroad are dummy variables indicating, respectively, publicly trade firms, firms that due to its incorporation form are bound to disclosure rules whether the firm is part of an economic group, exports, is controlled by foreigners and maintains operations abroad. Bank credit includes all the sources of formal loans. Formal sources are funds from a formal credit institution. Owners represent the funds coming from stockholders as equity or loans. Informal sources are all the sources not included among the formal sources. Trade credit represents all the funds generated from the operations of the firm. All regressions include dummy variables for industry sectors and the GDP per capita of the parentheses. \begin{tabular}{l|c|c|c|c|c}
\hline & \multicolumn{5}{|c}{ Source of external financing } \\
\hline Variable & Bank credit & Formal sources & Owners & Informal sources & Trade credit \\
\hline
\end{tabular}

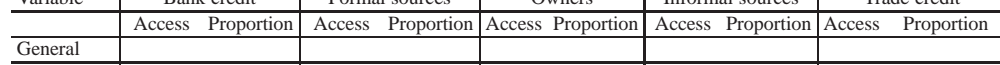

\begin{tabular}{l|ll|ll|ll|ll|ll}
\hline \multirow{2}{*}{ X micro } & -0.94 & -20.95 & -0.90 & -22.62 & 1.58 & 62.69 & $\mathbf{1 . 7 6}^{*}$ & 14.88 & -0.81 & 48.45 \\
\cline { 2 - 10 } & $(1.50)$ & $(0.64)$ & $(1.44)$ & $(0.81)$ & $(139)$ & $(0.86)$ & $(1.82)$ & $(0.24)$ & $(1.20)$ & $(124)$ \\
\hline
\end{tabular}

\begin{tabular}{l|cccc|ccc|cccc} 
& $(1.50)$ & $(0.64)$ & $(1.44)$ & $(0.81)$ & $(1.39)$ & $(0.86)$ & $(1.82)$ & $(0.24)$ & $(1.20)$ & $(1.24)$ \\
\cline { 2 - 11 } & X small & -0.39 & -31.24 & 0.02 & -26.49 & 1.44 & 45.24 & 1.37 & 5.52 & -0.48 & 27.30 \\
\cline { 2 - 11 } & $(0.66)$ & $(1.18)$ & $(0.81)$ & $(1.10)$ & $(1.29)$ & $(0.62)$ & $(1.45)$ & $(0.09)$ & $(0.76)$ & $(0.76)$ \\
\hline \multirow{2}{*}{ X medium } & -0.19 & -28.44 & $\mathbf{0 . 1 0}$ & -27.59 & 1.53 & 30.25 & 1.35 & -2.26 & -0.48 & 12.22 \\
\cline { 2 - 10 } & $(0.32)$ & $(1.09)$ & $(2.34)$ & $(1.15)$ & $(1.34)$ & $(0.40)$ & $(1.40)$ & $(0.04)$ & $(0.74)$ & $(0.34)$ \\
\hline \multirow{2}{*}{ X large } & 0.53 & -39.23 & -0.35 & -25.52 & 0.81 & 10.43 & 0.43 & 6.83 & 0.19 & 14.23 \\
\cline { 2 - 10 } & $(0.76)$ & $(1.32)$ & $(0.60)$ & $(0.95)$ & $(0.64)$ & $(0.14)$ & $(0.39)$ & $(0.11)$ & $(0.27)$ & $(0.36)$ \\
\hline
\end{tabular}

\begin{tabular}{|c|c|c|c|c|c|}
\hline & 8076 & $(0,95)$ & $6(0,64$ & $(0,39)$ & $(0.27)$ \\
\hline$\overline{\chi^{2}}$ & 81.9 & 90.0 & 646.6 & 1011.9 & 945.1 \\
\hline Observation & 1137 & 1137 & 1137 & 1137 & 1137 \\
\hline Lambda & -25.3 & -9.5 & -16.0 & -25.6 & -16.9 \\
\hline
\end{tabular}

\begin{tabular}{|c|c|c|c|c|c|}
\hline \multirow[t]{2}{*}{ Lambda } & -25.3 & -9.5 & -16.0 & -25.6 & -16.9 \\
\hline & $(1.00)$ & $(0.55)$ & $(0.46)$ & $(0.97)$ & $(0.88)$ \\
\hline Costs & & & & & \\
\hline $\mathrm{X}$ micro & $-0.86^{*}$ & -10.01 & $1.41^{* * *}$ & $1.83^{* * * *}$ & -0.72 \\
\hline
\end{tabular}

\begin{tabular}{l|cc|cc|cc|cc|cc} 
& $(1.73)$ & $(0.27)$ & $(1.62)$ & $(0.44)$ & $(1.88)$ & $(0.84)$ & $(2.95)$ & $(0.54)$ & $(1.31)$ & $(0.47)$ \\
\hline $\mathrm{X}$ small & -0.22 & -4.69 & -0.16 & -15.07 & $\mathbf{1 . 2 4} * *$ & 30.69 & $\mathbf{1 . 3 9 * *}$ & 17.65 & -0.35 & -6.90
\end{tabular}

\begin{tabular}{l|cc|cc|cc|cc|cc}
\hline & -0.22 & -4.69 & -0.16 & -15.07 & $\mathbf{1 . 2 4} 4^{* *}$ & 30.69 & $\mathbf{1 . 3 9} * *$ & 17.65 & -0.35 & -6.90 \\
\hline & $(0.51)$ & $(0.24)$ & $(0.37)$ & $(0.84)$ & $(1.77)$ & $(0.51)$ & $(2.38)$ & $(0.37)$ & $(0.71)$ & $(0.25)$ \\
\hline $\mathrm{X}$ medium & 0.04 & 2.36 & 0.09 & -11.74 & $\mathbf{1 . 3 4} * *$ & 16.84 & $\mathbf{1 . 3 2} * *$ & 8.51 & -0.39 & -21.46
\end{tabular}

\begin{tabular}{|c|c|c|c|c|c|c|c|c|c|c|}
\hline $\mathrm{X}$ medium & 0.04 & 2.36 & 0.09 & -11.74 & $1.34^{* * *}$ & 16.84 & $1.32^{* * *}$ & 8.51 & -0.39 & -21.46 \\
\hline & $(0.09)$ & $(0.12)$ & $(0.19)$ & $(0.64)$ & $(1.80)$ & $(0.26)$ & $(2.08)$ & $(0.17)$ & $(0.75)$ & $(0.74)$ \\
\hline X large & 0.96 & -6.90 & $1.10^{*}$ & -5.89 & 0.73 & -5.59 & 0.48 & 12.93 & 0.31 & -18.00 \\
\hline & $(1.52)$ & $(0.24)$ & $(1.73)$ & $(0.24)$ & $(0.76)$ & $(0.10)$ & $(0.55)$ & $(0.27)$ & $(0.47)$ & $(0.51)$ \\
\hline$\chi^{2}$ & \multicolumn{2}{|c|}{81.6} & \multicolumn{2}{|c|}{89.5} & \multicolumn{2}{|c|}{602.2} & \multicolumn{2}{|c|}{984.4} & \multicolumn{2}{|c|}{1034.2} \\
\hline
\end{tabular}

\begin{tabular}{|c|c|c|c|c|c|c|c|c|c|c|}
\hline$\chi^{2}$ & \multicolumn{2}{|c|}{81.6} & \multicolumn{2}{|c|}{89.5} & \multicolumn{2}{|c|}{602.2} & \multicolumn{2}{|c|}{984.4} & \multicolumn{2}{|c|}{1034.2} \\
\hline Observation & \multicolumn{2}{|c|}{1137} & \multicolumn{2}{|c|}{1137} & \multicolumn{2}{|c|}{1137} & \multicolumn{2}{|c|}{1137} & \multicolumn{2}{|c|}{1137} \\
\hline \multirow[t]{2}{*}{ Lambda } & \multirow{2}{*}{\multicolumn{2}{|c|}{$\begin{array}{r}-23.5 \\
0.94\end{array}$}} & \multirow{2}{*}{\multicolumn{2}{|c|}{$\begin{array}{c}-9.0 \\
0.52\end{array}$}} & \multirow{2}{*}{\multicolumn{2}{|c|}{$\begin{array}{c}-14.2 \\
(0.40) \\
\end{array}$}} & \multirow{2}{*}{\multicolumn{2}{|c|}{$\begin{array}{c}-25.58 \\
(0.93)\end{array}$}} & \multirow{2}{*}{\multicolumn{2}{|c|}{$\begin{array}{l}-16.5 \\
(0.86)\end{array}$}} \\
\hline & & & & & & & & & & \\
\hline \multicolumn{11}{|l|}{ Velocity } \\
\hline $\mathrm{X}$ micro & $\begin{array}{l}-0.31 \\
(0.81)\end{array}$ & $\begin{array}{l}-12.34 \\
(0.68)\end{array}$ & $\begin{array}{l}-0.32 \\
(0.84)\end{array}$ & $\begin{array}{l}-5.23 \\
(0.32) \\
\end{array}$ & $\begin{array}{c}0.35 \\
(0.58) \\
\end{array}$ & $\begin{array}{l}49.29 \\
(1.49)\end{array}$ & $\begin{array}{c}0.29 \\
(0.59) \\
\end{array}$ & $\begin{array}{l}13.97 \\
(0.48)\end{array}$ & \begin{tabular}{|c|}
-0.38 \\
$(0.92)$ \\
\end{tabular} & $\begin{array}{l}30.62 \\
(1.23)\end{array}$ \\
\hline $\bar{X}$ small & $\begin{array}{c}0.01 \\
(0.03)\end{array}$ & $\begin{array}{r}-18.47 \\
(1.15) \\
\end{array}$ & $\begin{array}{l}-0.00 \\
(0.00)\end{array}$ & $\begin{array}{l}7.37 \\
(0.50) \\
\end{array}$ & $\begin{array}{c}0.27 \\
(0.47) \\
\end{array}$ & $\begin{array}{l}39.42 \\
(1.21) \\
\end{array}$ & $\begin{array}{c}0.06 \\
(0.13) \\
\end{array}$ & $\begin{array}{c}8.56 \\
(0.31) \\
\end{array}$ & $\begin{array}{l}-0.19 \\
(0.50) \\
\end{array}$ & $\begin{array}{l}18.08 \\
(0.79) \\
\end{array}$ \\
\hline $\mathrm{X}$ medium & $\begin{array}{c}0.10 \\
(0.28)\end{array}$ & $\begin{array}{c}-17.65 \\
(1.09)\end{array}$ & $\begin{array}{c}0.10 \\
(0.29)\end{array}$ & $\begin{array}{l}-9.14 \\
(0.62)\end{array}$ & $\begin{array}{c}0.33 \\
(0.56)\end{array}$ & $\begin{array}{l}26.59 \\
(0.81)\end{array}$ & $\begin{array}{c}0.07 \\
(0.15)\end{array}$ & $\begin{array}{c}2.88 \\
(0.10)\end{array}$ & \begin{tabular}{|c|}
-0.17 \\
$(0.44)$
\end{tabular} & $\begin{array}{c}8.15 \\
(0.36)\end{array}$ \\
\hline $\mathrm{X}$ large & $\begin{array}{c}0.50 \\
(1.22) \\
\end{array}$ & $\begin{array}{l}-24.25 \\
(1.25) \\
\end{array}$ & $\begin{array}{c}0.54 \\
(1.31) \\
\end{array}$ & $\begin{array}{l}-8.38 \\
(0.50) \\
\end{array}$ & $\begin{array}{c}-0.13 \\
(0.20) \\
\end{array}$ & $\begin{array}{l}15.15 \\
(0.37) \\
\end{array}$ & $\begin{array}{c}-0.50 \\
(0.84) \\
\end{array}$ & $\begin{array}{c}8.42 \\
(0.22) \\
\end{array}$ & $\begin{array}{c}0.24 \\
(0.56) \\
\end{array}$ & $\begin{array}{c}8.79 \\
(0.36) \\
\end{array}$ \\
\hline$\chi^{2}$ & \multicolumn{2}{|c|}{80.7} & \multicolumn{2}{|c|}{88.5} & \multicolumn{2}{|c|}{503.5} & \multicolumn{2}{|c|}{721.94} & \multicolumn{2}{|c|}{985.9} \\
\hline Observation & \multicolumn{2}{|c|}{1137} & \multicolumn{2}{|c|}{1137} & \multicolumn{2}{|c|}{1137} & \multicolumn{2}{|c|}{1137} & \multicolumn{2}{|c|}{1137} \\
\hline Lambda & \multicolumn{2}{|c|}{$\begin{array}{l}-25.1 \\
(0.98)\end{array}$} & \multicolumn{2}{|c|}{$\begin{array}{c}-8.8 \\
(0.51)\end{array}$} & \multicolumn{2}{|c|}{$\begin{array}{c}-20.6 \\
(0.61)\end{array}$} & \multicolumn{2}{|c|}{$\begin{array}{c}-26.3 \\
(1.01)\end{array}$} & \multicolumn{2}{|c|}{$\begin{array}{l}-17.5 \\
(0.90)\end{array}$} \\
\hline \multicolumn{11}{|l|}{ Justice } \\
\hline$\overline{\mathrm{X} \text { micro }}$ & $\begin{array}{c}-\mathbf{2 . 1 3} \text { (2**** } \\
(2.79)\end{array}$ & $\begin{array}{c}-30.64 \\
(0.58)\end{array}$ & $\begin{array}{c}-\mathbf{- 2 . 1 1} \\
(2.78)\end{array}$ & $\begin{array}{l}-30.70 \\
(0.73) \\
\end{array}$ & $\begin{array}{c}0.93 \\
(0.86)\end{array}$ & $\begin{array}{l}29.68 \\
(0.43)\end{array}$ & $\begin{array}{c}1.25 \\
(1.36)\end{array}$ & $\begin{array}{l}-16.48 \\
(0.32) \\
\end{array}$ & $\begin{array}{c}-1.19 \\
(1.41)\end{array}$ & $\begin{array}{l}102.43 \\
(0.92)\end{array}$ \\
\hline $\bar{X}$ small & $\begin{array}{c}-1.06^{*} \\
(1.65)\end{array}$ & $\begin{array}{c}-44.56 \\
(1.37)\end{array}$ & $\begin{array}{l}-1.04 \\
(1.63)\end{array}$ & $\begin{array}{c}-35.22 \\
(1.30) \\
\end{array}$ & $\begin{array}{c}0.60 \\
(0.63)\end{array}$ & $\begin{array}{c}-15.37 \\
(0.25)\end{array}$ & $\begin{array}{c}0.54 \\
(0.67)\end{array}$ & $\begin{array}{r}-37.76 \\
(0.83) \\
\end{array}$ & $\begin{array}{l}-0.51 \\
(0.72)\end{array}$ & $\begin{array}{l}53.28 \\
(0.88)\end{array}$ \\
\hline$\overline{\mathrm{X} \text { medium }}$ & $\begin{array}{c}-0.70 \\
(0.98)\end{array}$ & $\begin{array}{l}-41.62 \\
(1.33)\end{array}$ & $\begin{array}{c}-0.64 \\
(0.90)\end{array}$ & $\begin{array}{c}-40.99 \\
(1.53)\end{array}$ & $\begin{array}{c}0.81 \\
(0.73)\end{array}$ & $\begin{array}{r}-26.85 \\
(0.38) \\
\end{array}$ & $\begin{array}{c}0.56 \\
(0.59)\end{array}$ & $\begin{array}{c}-39.84 \\
(0.76)\end{array}$ & $\begin{array}{c}-0.64 \\
(0.79) \\
\end{array}$ & $\begin{array}{l}45.66 \\
(1.27)\end{array}$ \\
\hline$\overline{\mathrm{X} \text { large }}$ & $\begin{array}{c}0.73 \\
(0.72)\end{array}$ & $\begin{array}{l}-66.32 \\
(1.70)\end{array}$ & $\begin{array}{c}0.88 \\
(0.87)\end{array}$ & $\begin{array}{l}-39.72 \\
(1.14)\end{array}$ & $\begin{array}{c}-1.04 \\
(0.59)\end{array}$ & $\begin{array}{r}-83.10 \\
(0.71)\end{array}$ & $\begin{array}{c}-1.68 \\
(1.02)\end{array}$ & $\begin{array}{c}-40.24 \\
(0.36)\end{array}$ & $\begin{array}{c}0.64 \\
(0.59)\end{array}$ & $\begin{array}{c}\mathbf{1 2 5 . 9} \\
(1.74)\end{array}$ \\
\hline$\chi^{2}$ & & & & & & & & & & 43.5 \\
\hline Observation & & & & & & & & & & 137 \\
\hline Lambda & & & & & & & & & & $\begin{array}{l}7.8 \\
91)\end{array}$ \\
\hline
\end{tabular}


The effect of financial development on external financing (Tables 11 and 12) is a clear picture: financial development increases the access to bank credit and formal sources of funds: all the three indexes present positive sign that is statistically significant at the one percent level. However, there is no effect on the proportion in which these sources contributes to the financing of investments. Financial development does not present any effect on the recourse to owners' funds, informal sources or trade credit. However, it reduces the proportion of informal sources and trade credit.

Table 11

Effects of institutional development on external finance - Financial development

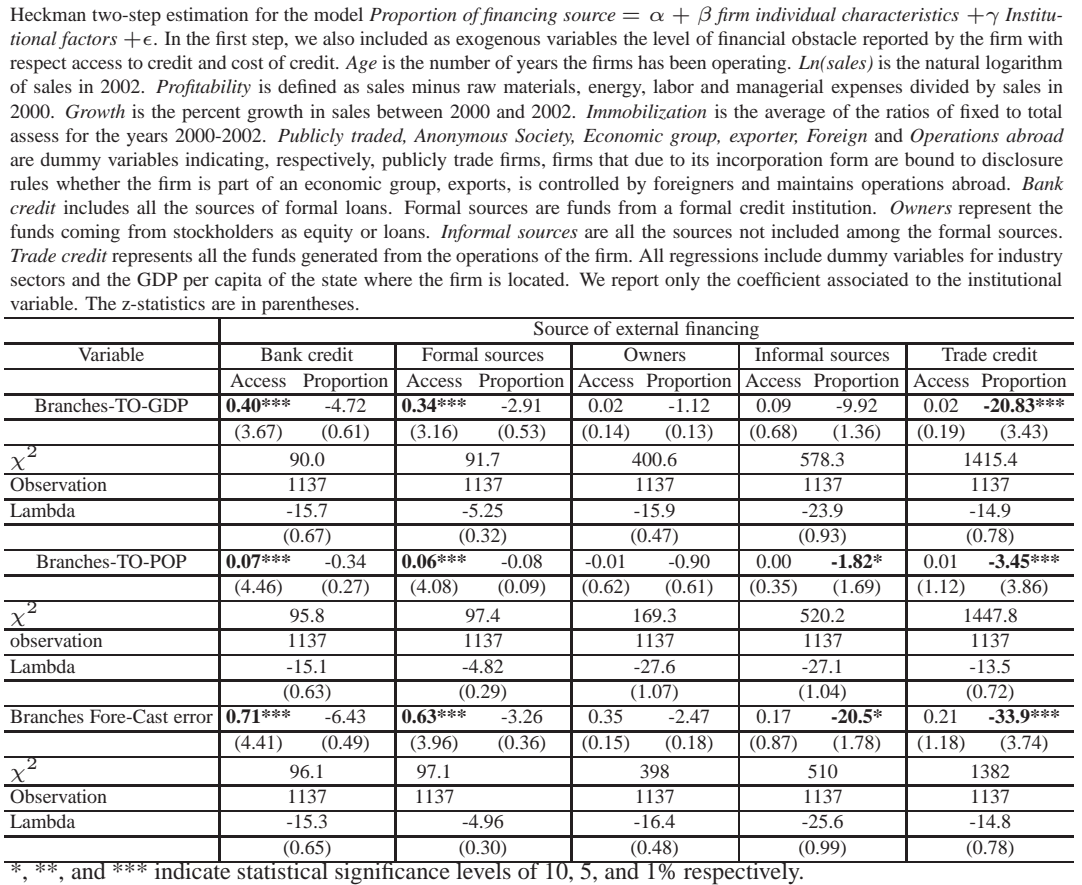


Table 12

Effects of institutional development on external finance - Financial development

Heckman two-step estimation for the model Proportion of financing source $=\alpha+\beta$ firm individual characteristics $+\gamma$ Institutional factors $+\epsilon$. In the first step, we also included as exogenous variables the level of financial obstacle reported by the firm with respect access to credit and cost of credit. Age is the number of years the firms has been operating. Ln(sales) is the natural logarithm of sales in 2002. Profitability is defined as sales minus raw materials, energy, labor and managerial expenses divided by sales in 2000. Growth is the percent growth in sales between 2000 and 2002. Immobilization is the average of the ratios of fixed to total assess for the years 2000-2002. Publicly traded, Anonymous Society, Economic group, exporter, Foreign and Operations abroad are dummy variables indicating, respectively, publicly trade firms, firms that due to its incorporation form are bound to disclosure rules whether the firm is part of an economic group, exports, is controlled by foreigners and maintains operations abroad. Bank credit includes all the sources of formal loans. Formal sources are funds from a formal credit institution. Owners represent the funds coming from stockholders as equity or loans. Informal sources are all the sources not included among the formal sources. Trade credit represents all the funds generated from the operations of the firm. All regressions include dummy variables for industry sectors and the GDP per capita of the state where the firm is located. We report only the coefficient associated to the institutional variable. The z-statistics are in parentheses.

\begin{tabular}{|c|c|c|c|c|c|c|c|c|c|c|}
\hline \multirow{3}{*}{ Variable } & \multicolumn{10}{|c|}{ Source of external financing } \\
\hline & \multicolumn{2}{|c|}{ Bank credit } & \multicolumn{2}{|c|}{ Formal sources } & \multicolumn{2}{|c|}{ Owners } & \multicolumn{2}{|c|}{ Informal sources } & \multicolumn{2}{|c|}{ Trade credit } \\
\hline \multirow{2}{*}{\multicolumn{11}{|c|}{ 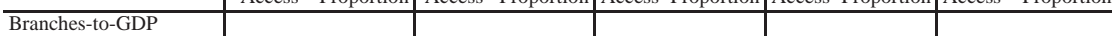 }} \\
\hline & & & & & & & & & & \\
\hline \multirow[t]{2}{*}{$\mathrm{X}$ micro } & 0.16 & -5.30 & 0.12 & -3.64 & -0.01 & 10.62 & 0.11 & -5.52 & -0.08 & $-11.15^{*}$ \\
\hline & $(1.46)$ & $(1.02)$ & $(1.16)$ & $(0.82)$ & $(0.08)$ & $(1.15)$ & $(0.85)$ & $(0.66)$ & $(0.69)$ & $(1.68)$ \\
\hline \multirow[t]{2}{*}{$\mathrm{X}$ small } & $0.32 * * *$ & -7.70 & $0.29 * * *$ & -4.65 & -0.01 & 2.47 & 0.08 & -9.55 & 0.01 & $-16.49^{* * * *}$ \\
\hline & $(3.25)$ & $(1.09)$ & $(2.99)$ & $(0.91)$ & $(0.08)$ & $(0.30)$ & $(0.68)$ & $(1.28)$ & $(0.13)$ & $(2.95)$ \\
\hline \multirow[t]{2}{*}{$\mathrm{X}$ medium } & $0.37 * * *$ & -6.37 & $0.35 \% * *$ & -4.45 & 0.07 & -2.89 & 0.12 & -12.49 & 0.03 & $-20.16^{* * * *}$ \\
\hline & $(3.65)$ & $(0.82)$ & $(3.45)$ & $(0.80)$ & $(0.48)$ & $(0.32)$ & $(0.95)$ & $(1.53)$ & $(0.28)$ & $(3.63)$ \\
\hline \multirow[t]{2}{*}{$\mathrm{X}$ large } & $0.55 * * *$ & -8.26 & $0.55 * * *$ & -3.50 & -0.03 & -10.68 & -0.03 & -11.63 & 0.19 & $-17.45^{* * * *}$ \\
\hline & $(4.23)$ & $(0.80)$ & $(4.21)$ & $(0.47)$ & $(0.18)$ & $(0.93)$ & $(0.19)$ & $(1.08)$ & $(1.46)$ & $(2.58)$ \\
\hline$\chi^{2}$ & \multicolumn{2}{|c|}{101.6} & \multicolumn{2}{|c|}{106.3} & \multicolumn{2}{|c|}{366.2} & \multicolumn{2}{|c|}{614.6} & \multicolumn{2}{|c|}{1073.4} \\
\hline Observation & \multicolumn{2}{|c|}{1137} & \multicolumn{2}{|c|}{1137} & \multicolumn{2}{|c|}{1137} & \multicolumn{2}{|c|}{1137} & \multicolumn{2}{|r|}{1137} \\
\hline Lambda & \multicolumn{2}{|c|}{$\begin{array}{l}-18.6 \\
(0.73)\end{array}$} & \multicolumn{2}{|c|}{$\begin{array}{c}-5.9 \\
(0.34) \\
\end{array}$} & & $\begin{array}{l}19.7 \\
.57) \\
\end{array}$ & & $\begin{array}{l}32.9 \\
1.17) \\
\end{array}$ & & $\begin{array}{l}-15.0 \\
(0.79) \\
\end{array}$ \\
\hline Branches-to-popu & & & & & & & & & & \\
\hline $\mathrm{X}$ micro & $0.03 * *$ & -0.53 & $0.03^{* * *}$ & -0.28 & -0.00 & 1.45 & 0.01 & -1.31 & 0.00 & $-2.62 * * *$ \\
\hline & $(2.23)$ & $(0.57)$ & $(2.05)$ & $(0.39)$ & $(0.35)$ & $(1.02)$ & $(0.73)$ & $(1.06)$ & $(0.26)$ & $(2.62)$ \\
\hline $\mathrm{X}$ small & $0.05 * * *$ & -0.82 & $0.05 \% * *$ & -0.33 & -0.01 & 0.37 & 0.00 & -1.51 & 0.01 & $-3.10 \% * *$ \\
\hline & $(4.01)$ & $\begin{array}{l}(0.68) \\
\end{array}$ & $(3.84)$ & $(0.39)$ & $(0.54)$ & $(0.31)$ & $(0.16)$ & $(1.51)$ & $(1.24)$ & $(3.57)$ \\
\hline $\mathrm{X}$ medium & $0.06 * * * * *$ & 0.57 & $0.06 * * *$ & -0.31 & -0.00 & -0.17 & 0.00 & -1.57 & 0.01 & $-3.53 * * * *$ \\
\hline & \begin{tabular}{|l|}
$(4.02)$ \\
\end{tabular} & $(0.46)$ & $(3.97)$ & $(0.35)$ & $(0.21)$ & $(0.15)$ & $(0.37)$ & $(1.44)$ & $(1.11)$ & $(4.09)$ \\
\hline $\mathrm{X}$ large & $0.07 * * *$ & 0.67 & $0.07^{* *}$ & -0.04 & -0.03 & -1.43 & -0.02 & -0.99 & $0.04 * *$ & $-3.03^{* * * *}$ \\
\hline & $(4.04)$ & $(0.44)$ & $(4.03)$ & $(0.04)$ & $(0.98)$ & $(0.72)$ & $(0.91)$ & $(0.54)$ & $(2.19)$ & $(2.69)$ \\
\hline$\chi^{2}$ & & 9.7 & & 04.1 & & 05.6 & & 331.2 & & 1554.8 \\
\hline Observation & & 37 & & 137 & & 137 & & 1137 & & 1137 \\
\hline Lambda & & $\begin{array}{l}7.4 \\
68) \\
\end{array}$ & & $\begin{array}{l}5.3 \\
.30) \\
\end{array}$ & & $\begin{array}{l}8.1 \\
.52) \\
\end{array}$ & & $\begin{array}{l}-32.1 \\
1.16) \\
\end{array}$ & & $\begin{array}{l}-12.4 \\
(0.67)\end{array}$ \\
\hline Branches Fore-Ca & & & & & & & & & & \\
\hline $\mathrm{X}$ micro & 0.33 & -6.52 & -0.11 & -6.54 & -0.04 & $85.8^{* * *}$ & -0.32 & 14.4 & -0.28 & -27.3 \\
\hline & $(0.09)$ & $(0.36)$ & $(0.30)$ & $(0.37)$ & $(0.08)$ & $(2.64)$ & $(0.72)$ & $(0.54)$ & $(0.70)$ & $(1.27)$ \\
\hline $\bar{X}$ small & $0.81 * * *$ & -21.0 & $0.74 * * *$ & -14.1 & -0.10 & -19.2 & 0.28 & $-30.8 * *$ & 0.35 & $-37.5 * * *$ \\
\hline & $(3.88)$ & $(1.27)$ & $(3.56)$ & (1.19) & $(0.33)$ & $(1.06)$ & $(1.10)$ & $(1.97)$ & $(1.51)$ & $(2.85)$ \\
\hline$\overline{\mathrm{X} \text { medium }}$ & $0.76 * * *$ & 3.53 & $\overline{0.71^{* *}}$ & 2.24 & 0.40 & -16.9 & 0.42 & -22.6 & 0.03 & $-45.3 * * *$ \\
\hline & $(2.65)$ & $(0.21)$ & $(2.47)$ & $(0.18)$ & $(0.95)$ & $(0.63)$ & $(1.12)$ & $(0.94)$ & $(0.09)$ & $(2.92)$ \\
\hline $\mathrm{X}$ large & $1.26 * *$ & -0.51 & $1.33^{* *}$ & 12.4 & 0.19 & -76.8 & 0.03 & -42.7 & 0.83 & -23.1 \\
\hline & $(2.31)$ & $(0.02)$ & $(2.37)$ & $(0.62)$ & $(0.22)$ & $(1.40)$ & $(0.04)$ & $\begin{array}{l}(0.77) \\
\end{array}$ & $(1.50)$ & $(0.81)$ \\
\hline$\chi^{2}$ & & 3.8 & & 66.37 & & 375 & & 482.6 & & 1420 \\
\hline observation & & 37 & & 137 & & 137 & & 1137 & & 1137 \\
\hline Lambda & & $\begin{array}{l}9.8 \\
79)\end{array}$ & & $\begin{array}{l}0.38 \\
1.01)\end{array}$ & & $\begin{array}{l}29.8 \\
9.86)\end{array}$ & & $\begin{array}{l}30.7 \\
1.09)\end{array}$ & & $\begin{array}{l}-13.6 \\
(0.72)\end{array}$ \\
\hline
\end{tabular}

$*, * *$, and $* * *$ indicate statistical significance levels of 10,5 , and $1 \%$ respectively. 
There is also a clear picture on how financial development differently affects small and large firms: it improves the access to bank credit and formal sources for all sizes of firms. However, the effect is monotonic: large firms benefit the most. Financial development has no effect on the proportion of these sources of financing for any size of firm. The effect of financial development on reducing the proportion of trade credit is more pronounced for small and medium firm than it is for micro and large ones.

\section{Conclusions}

This article investigates how institutional development at the state level can explain how Brazilian firms choose the external sources of financing for their new investments. It uses a cross-state approach based on the existing variation across Brazilian states in terms of corruption, inefficiency of the judicial system and financial development. Differently from traditional studies on capital structure, we consider sources of funds other than formal debt and equity finance. We also model the firm-level self-selection that occurs when accessing a particular source of financing.

Our results are based on a unique dataset, the Investment Climate Survey (ICS) of the Worldbank. This dataset was stratified to be representative across size (71.9\% of the sample are firms with less than 100 employees); 13 federal states; and 9 industry sectors. By using such unique dataset we were able to test how institutional development affects the use of the distinct sources of external financing and how it differently affects small and large firms. This is only possible because out dataset is representative across size. This fills a gap because most studies on Brazilian corporate finance are based on datasets containing mostly medium and large firms.

With respect to the effects of firm's individual characteristics on the external financing we found that 1) the use of bank credit is affected only by size and growth; 2) the use of formal sources is conditioned by size, growth, foreign proprietorship and exportation activity; 3) financing by owners is influenced by age, immobilization, foreign control, form of incorporation, exportation activity and economic group. The proportion of financing from owners seems to be affected only by the degree of immobilization; 4) the use of informal source is less frequent for firm that are old, large and incorporated as anonymous society, and more frequent for those that have foreign control, belong to an economic group, and present high degree of immobilization. The proportion of informal sources decreases with immobilization and is larger for firms with foreign control; and 5) the use of trade credit is more frequent for old firms and those with operations abroad, while the proportion of this source of funds decreases with size and growth.

Considering the effect of institutional development on the external financing, our analysis indicated that 1) corruption has a negative effect on the access to bank credit, formal sources and trade credit, and that this effect is more severe on smallest firms. Corruption also seems to cause firms to use a higher proportion 
of trade credit and informal sources, even though one can not distinguish whether this effect varies with the size of the firm; 2) the effect of the inefficiency of the judicial system is very similar to that of corruption: negative effect on the access to bank credit, formal sources and trade credit. This effect seems to be more severe on smallest firms. It also seems to cause firms to rely more on funds from owners and informal sources. This last effect is stronger on smallest firms; and 3) financial development increases the access to bank credit and formal sources of funds and reduces the proportion of informal sources and trade credit. Large firms benefit the most from the extended access to bank credit and formal sources. For all size of firms, financial development reduces the proportion of trade credit.

Our main results are that corruption and inefficiency of the judicial system have a negative impact on the access to bank credit and formal sources of funds. Financial development has a positive impact on the use of the same sources. Furthermore, this effect is more severe on smallest firms. These results suggest that low institutional development can foster financial repression making firms to rely more intensively on informal sources of funds or, otherwise, limit their investments. These results are in lines and help to explain De Carvalho (2008) that found that 1) shortcomings of institutional development, when measured in terms of corruption and inefficiency of the judicial system have a negative impact on firm growth. Financial development at the states level has a positive effect on growth and 2) that smallest firms are those who suffer the most with corruption and inefficiency of the judicial system and largest firms are the one that profit the most from financial development.

Overall our results indicate that improvement in institutions can be an important mechanism to alleviate financial repression. Furthermore, institutional underdevelopment has the perverse effect of promoting industrial concentration.

\section{References}

Barros, L. A. B. C. \& Da Silveira, A. D. M. (2007). Overconfidence, managerial optimism and the determinants of capital structure. Working paper. Available at SSRN: http://ssrn.com/abstract=953273.

Beck, T., Demirguc-Kunt, A., \& Maksimovic, V. (2008). Financing patterns around the world: The role of institutions. Journal of Financial Economics, 90:467-487.

Black, F. \& Scholes, M. (1973). The pricing of options and corporate liabilities. Journal of Political Economy, 81:637-654.

Booth, L., Aivazian, V., Demirguc-Kunt, A., \& Maksimovic, V. (2001). Capital structure in developing countries. Journal of Finance, 56:87-130.

Campello, M. (2003). Capital structure and product markets interactions: Evidence from business cycles. Journal of Financial Economics, 68:353-378. 
De Carvalho, A. G. (2008). The effect of institutional development on the growth of Brazilian firms. Revista Brasileira de Economia, 62:1-17.

Demirgüç-Kunt, A. \& Maksimovic, V. (1996). Stock market development and firm financing choices. World Bank Economic Review, 10:341-371.

Demirgüç-Kunt, A. \& Maksimovic, V. (1998). Law, finance, and firm growth. Journal of Finance, 53:2107-2137.

Demirgüç-Kunt, A. \& Maksimovic, V. (1999). Institutions, financial markets and firm debt maturity. Journal of Financial Economics, 54:295-336.

Jensen, M. \& Meckling, W. (1976). Theory of the firm: Managerial behavior, agency costs and ownership structure. Journal of Financial Economics, 3:305360.

La Porta, R., Lopez-de Silanes, F., Shleifer, A., \& Vishny, R. (1997). Legal determinants of external finance. Journal of Finance, 52:1131-1150.

La Porta, R., Lopez-de Silanes, F., Shleifer, A., \& Vishny, R. (1998). Law and finance. Journal of Political Economy, 106:1113-1155.

Leal, R. P. C. \& Da Silva, A. L. C. (2007). O financiamento externo no ciclo recente da economia brasileira. United Nations - CEPAL Working paper.

Levy, A. Hennessy, C. (2007). Why does capital structure choice vary with macroeconomic conditions. Journal of Monetary Economics, 54:1545-1564.

Love, I. (2003). Financial development and financing constraints: International evidence from the structural investment model. Word Bank Working Paper \#2694.

Miller, M. (1977). Debt and taxes. Journal of Finance, 32:261-276.

Modigliani, F. \& Miller, M. (1958). The cost of capital, corporate finance, and the theory of investment. American Economic Review, 48:261-297.

Modigliani, F. \& Miller, M. (1963). Corporate income taxes and the cost of capital: A correction. American Economic Review, 53:443-453.

Myers, S. (2003). Financing of corporations. In Constantinides, G. M., Harris, M., \& Stulz, R., editors, Handbook of the Economics of Finance, Volume 1A: Corporate Finance. Elzevier B. V.

Myers, S. C. (1984). The capital structure puzzle. Journal of Finance, 39(3):575592.

Myers, S. C. \& Majluf, N. S. (1984). Corporate financing and investment decisions when firms have information that investors do not have. Journal of Financial Economics, 13(2):187-221. 
Pinheiro, A. C. \& Cabral, C. (1998). Mercado de crédito no brasil: O papel do judiciário e de outras instituições. Ensaios BNDES 9.

Procianoy, J. L. \& Schnorrenberger, A. (2004). A influência da estrutura de controle nas decisões de estrutura de capital das companhias brasileiras. Revista Brasileira de Economia, 58:121-146.

Rajan, R. \& Zingales, L. (1998). Financial dependence and growth. American Economic Review, 88:559-587.

Shleifer, A. \& Wolfenzon, D. (2002). Investor protection and equity markets. Journal of Financial Economics, 66:3-27.

Smith, C. \& Warner, J. (1979). On financial contracting: An analysis of bond covenants. Journal of Financial Economics, 7:117-161.

Stiglitz, J. \& Weiss, A. (1981). Credit rationing in markets with imperfect information. American Economic Review, 71:393-410. 